\title{
Fc-Engineered Antibodies with Enhanced Fc-Effector Function for the Treatment of B-Cell Malignancies
}

\author{
Hilma J. van der Horst * ${ }^{(}$, Inger S. Nijhof, Tuna Mutis and Martine E. D. Chamuleau \\ Department of Hematology, Cancer Center Amsterdam, Amsterdam UMC, VU Medical Center, 1081 HV \\ Amsterdam, The Netherlands; i.nijhof@amsterdamumc.nl (I.S.N.); t.mutis@amsterdamumc.nl (T.M.); \\ m.chamuleau@amsterdamumc.nl (M.E.D.C.) \\ * Correspondence: h.vanderhorst1@amsterdamumc.nl
}

Received: 21 September 2020; Accepted: 14 October 2020; Published: 19 October 2020

Simple Summary: Monoclonal antibody $(\mathrm{mAb})$ therapy has been an important addition to the therapeutic arsenal in B-cell malignancies. MAbs can induce cytotoxicity against B-cell malignancies by antibody effector functions mediated via their fragment crystallizable $(\mathrm{Fc})$ region. In order to enhance the anti-tumor potential of antibodies, various Fc-engineering strategies have been developed. In this review we summarize the well-established as well as recently developed Fc-engineering strategies which are aimed to increase Fc-effector function and to enhance the anti-tumor potency of mAbs. In addition, the increased number of Fc-engineered mAbs in (pre-)clinical development asks for a clear overview describing the specific type of Fc-engineering, their antigen and disease target, and the current developmental stage, which we aimed to provide in this review.

\begin{abstract}
Monoclonal antibody $(\mathrm{mAb})$ therapy has rapidly changed the field of cancer therapy. In 1997, the CD20-targeting mAb rituximab was the first mAb to be approved by the U.S. Food and Drug Administration (FDA) for treatment of cancer. Within two decades, dozens of mAbs entered the clinic for treatment of several hematological cancers and solid tumors, and numerous more are under clinical investigation. The success of mAbs as cancer therapeutics lies in their ability to induce various cytotoxic machineries against specific targets. These cytotoxic machineries include antibody-dependent cellular cytotoxicity (ADCC), antibody-dependent cellular phagocytosis $(\mathrm{ADCP})$, and complement-dependent cytotoxicity (CDC), which are all mediated via the fragment crystallizable $(\mathrm{Fc})$ domain of $\mathrm{mAbs}$. In this review article, we will outline the novel approaches of engineering these $\mathrm{Fc}_{\mathrm{c}}$ domains of mAbs to enhance their Fc-effector function and thereby their anti-tumor potency, with specific focus to summarize their (pre-) clinical status for the treatment of B-cell malignancies, including chronic lymphocytic leukemia (CLL), B-cell non-Hodgkin lymphoma (B-NHL), and multiple myeloma (MM).
\end{abstract}

Keywords: antibody therapy; Fc engineering; immunotherapy; B-cell malignancies; B-cell lymphoma; B-CLL; multiple myeloma

\section{Introduction}

Naturally, antibodies (Abs) are produced by B-cells as a polyclonal population, with high specificity for their distinct target antigen and epitope. Antibodies thereby play various important roles in our immune system. The field of therapeutic Abs commenced in 1975, when the development of the mouse hybridoma technology enabled the production of large amounts of murine monoclonal $(\mathrm{m})$ Abs [1]. However, murine mAbs elicited an immunogenic response in human patients. To reduce this immunogenicity, chimeric mAbs, consisting of a constant human domain fused to a variable mouse domain, were developed [2]. The chimeric mAb rituximab targeting cluster of differentiation 
(CD) 20 was the first FDA-approved mAb for cancer therapy in 1997. The development of advanced design technologies such as human antibody gene expression libraries and transgenic animals allowed the engineering of humanized (the hypervariable region of a murine antibody grafted in a human antibody) and fully human mAbs [3]. To be successfully applied in the clinic, mAbs generally require additional engineering to improve their affinity, limit any biophysical liabilities, and to increase their half-life. Currently, $30 \mathrm{mAbs}$ are clinically approved for treatment of cancer, and this number is rapidly increasing: in the last decade, the number of mAbs that have entered late-stage clinical studies has been tripled [4]. The therapeutic potential of mAbs has been exploited by the development of antibody fusion products, such as bispecific antibodies or antibody drug conjugates, which take advantage of specific antigen binding properties of antibodies to precisely target cytotoxic cells or toxic agents to cancerous cells. A novel development in antibody engineering is the modification of the antibody fragment crystallizable $\left(\mathrm{Fc}_{\mathrm{c}}\right)$ region in order to increase the Fc tail-mediated effector functions, including antibody-dependent cellular cytotoxicity (ADCC), antibody-dependent cellular phagocytosis (ADCP), and complement-dependent cytotoxicity (CDC), to induce tumor cytotoxicity more effectively. Numerous Fc-engineered antibodies have demonstrated clinical activity or are under preclinical investigation.

In this review, we will outline the novel approaches of engineering Fc domains of mAbs to enhance their Fc-effector function and anti-tumor potency, with specific focus to their (pre-) clinical status for the treatment of B-cell malignancies, including chronic lymphocytic leukemia (CLL), B-cell non-Hodgkin lymphoma (B-NHL), and multiple myeloma (MM). Not described in this review is the application of Fc engineering in order to improve antibody half-life, to silence mAb effector functions in case of antibodies used as receptor agonists or antagonists or as drug delivery vehicles, and to increase the direct, not Fc-effector function-mediated, anti-tumor potency of mAbs.

\section{Antibody Structure}

Antibodies are mono- or polymers of immunoglobulins (Ig) consisting of two identical pairs of heavy $(\mathrm{H})$ and light $(\mathrm{L})$ chains, which are linked through non-covalent interactions and disulfide bonds to form a Y-shaped structure [5]. All H and L light chains contain a single variable domain $\left(V_{L}\right)$, which also consists of hypervariable regions. The combination of the (hyper) variable regions of the $\mathrm{H}$ and $\mathrm{L}$ chains determines the antigen specificity and affinity of an antibody. The $\mathrm{L}$ chains contain a single constant $\left(\mathrm{C}_{\mathrm{L}}\right)$ domain to make a stable link with the $\mathrm{H}$ chain. The number of constant domains of the $\mathrm{H}$ chain $\left(\mathrm{C}_{\mathrm{H}}\right)$ is dependent on the isotype of the antibody: $\operatorname{IgA}, \operatorname{IgD}$, and $\operatorname{IgG}$ contain three $\left(C_{H} 1-3\right)$, and $\operatorname{IgE}$ and IgM contain four constant domains $\left(C_{H} 1-4\right)$. The first $C_{H}$ is linked with $C_{L}$ to the variable regions, which together form the fragment antigen binding (Fab) region. The heavily glycosylated $\mathrm{C}_{\mathrm{H}} 2-3$ or $\mathrm{C}_{\mathrm{H}} 2-4$ domains are linked to $\mathrm{C}_{\mathrm{H}} 1$ via a flexible hinge region and constitute the $F_{C}$ region (Figure 1A). The engineering of this region, which is responsible for the isotype- and subclass-dependent Fc-mediated effector functions of antibodies, will be the main focus of this review. 
A

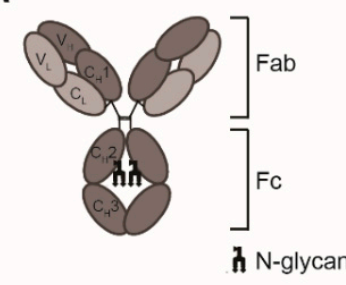

B

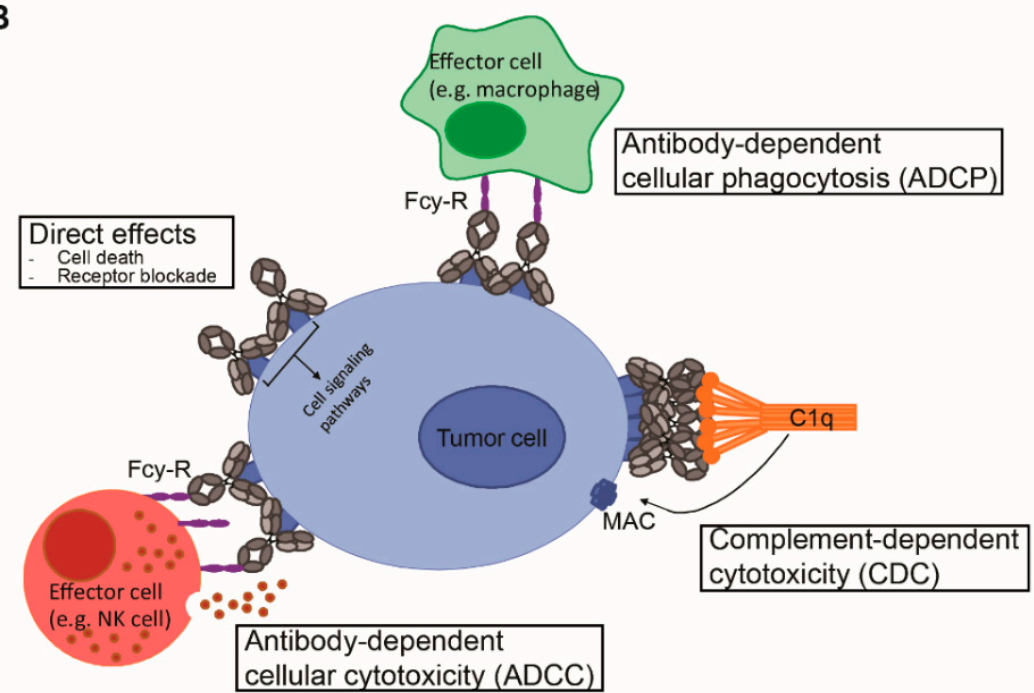

Figure 1. mAb structure and mechanisms of action. (A) Schematic representation of an IgG antibody consisting of variable $(\mathrm{V})$ and constant $(\mathrm{C})$ domains of the light ( $\mathrm{L}$; light grey) and heavy (H; dark grey) chains. The fragment antigen binding (Fab) domain is made up of $\mathrm{V}_{\mathrm{L}}$ and $\mathrm{C}_{\mathrm{L}}$ together with $\mathrm{V}_{\mathrm{H}}$ and $\mathrm{C}_{\mathrm{H}} 1$, and the fragment crystallizable $(\mathrm{Fc})$ region consists of $\mathrm{C}_{\mathrm{H}} 2$ and $\mathrm{C}_{\mathrm{H}} 3$, with an $\mathrm{N}$-glycan attached to $\mathrm{C}_{\mathrm{H}}$ 2. (B) Mechanisms of action of IgG1 mAbs consist of direct effects, including cell death and receptor blockade, and indirect effects, including antibody-dependent cellular cytotoxicity (ADCC), antibody-dependent cellular phagocytosis (ADCP) and complement-dependent cytotoxicity (CDC). $\mathrm{ADCC}$ and $\mathrm{ADCP}$ are mediated via binding to $\mathrm{Fc} \gamma \mathrm{R}$ and cell death occurs via release of cytotoxic granules and via internalization and degradation of the target, respectively. CDC is mediated via binding to complement protein $\mathrm{C} 1 \mathrm{q}$ and cell death occurs via formation of the membrane attack complex (MAC), which consists of complement proteins $\mathrm{C} 5 \mathrm{~b}, \mathrm{C} 6, \mathrm{C} 7$, and $\mathrm{C} 8$ and various copies of $\mathrm{C} 9$, and generates pores in the membrane.

\section{Fc-Effector Functions}

Upon antigen engagement, IgG antibodies can induce direct anti-tumor effects via triggering the cell death signaling pathways and via blockade of essential receptor systems, as well as indirect anti-tumor effects via their Fc-mediated effector functions, by engaging other immune cells or killer mechanisms. The Fc-mediated effector functions of antibodies include antibody-dependent cellular cytotoxicity (ADCC), antibody-dependent cellular phagocytosis (ADCP), and complement-dependent cytotoxicity (CDC), and have been shown to be crucial for the therapeutic efficacy of most clinically approved antibodies (Figure 1B). Among the four IgG subclasses, IgG1 and IgG3 induce the strongest Fc-effector functions [6]. However, since IgG1 has the longest half-life and is more stable than IgG3 [7], most therapeutic antibodies with Fc-mediated functions are of IgG1 isotype.

\section{1. $A D C C / A D C P$}

The IgG1-induced ADCC and ADCP response is mediated via binding to Fc gamma receptors $(\mathrm{Fc} \gamma \mathrm{R})$, which are expressed on innate effector cells, including monocytes, monocyte-derived cells, basophils, mast cells, and natural killer (NK) cells. The Fc $\gamma \mathrm{R}$ family consists of the activating Fc $\gamma \mathrm{RI}$ (CD64), Fc $\gamma$ RIIa (CD32a), Fc $\gamma$ RIIIa (CD16a), and Fc $\gamma$ RIIIb (CD16b), and the inhibitory Fc $\gamma$ RIIb (CD32b). Of all Fc $\gamma$ Rs, only Fc $\gamma$ RI, which plays a major role in myeloid cell activation, is classified as a high-affinity Fc receptor [8]. All other Fc $\gamma$ Rs require binding of multivalent IgG-antigen immune complexes in order to provide sufficient avidity to activate downstream signaling and induce antibody-mediated ADCC or ADCP [9].

Natural killer (NK) cells are considered the most potent inducers of ADCC. NK cells as well as monocytes and macrophages express Fc $\gamma$ RIIIa, however, only NK cells exclusively express Fc $\gamma$ RIIIa [10]. 
Triggering of Fc $\gamma$ RIIIa induces phosphorylation of immunoreceptor tyrosine-based activation motifs (ITAMs), which activates a downstream signaling cascade resulting in the release of cytotoxic granules containing perforin and granzyme in the immune synapse formed between the NK cell and the target cell, leading to target cell death [11].

In contrast to NK cells, the phagocytic monocytes, neutrophils, and macrophages co-express activating and inhibitory Fc $\gamma$ Rs. ADCP can be induced by various activating Fc $\gamma$ Rs including Fc $\gamma$ RIIIa (CD16a), Fc $\gamma$ RIIa (CD32A), and Fc $\gamma$ RIIIb (CD16b), which all signal via ITAMs, and may be inhibited by Fc $\gamma$ RIIb (CD32b), which signals via immunoreceptor tyrosine-based inhibitory motifs (ITIMs). The balance of activating and inhibitory signaling dictates ADCP induction, which occurs via internalization and degradation of the antibody-opsonized target by the phagocyte [12].

Fc $\gamma$ Rs are highly polymorphic, their genes are known to have several single-nucleotide polymorphisms (SNPs). Such polymorphisms can affect the affinity of the Fc $\gamma \mathrm{R}$ for Ig molecules [13]. Both Fc $\gamma$ RIIa and Fc $\gamma$ RIIIa are known to exist as two allotypic variants, which are associated with clinical response for therapeutic mAbs. In the extracellular domain of Fc $\gamma$ RIIa, a $C>T$ substitution at amino acid position 131 results in a histidine (131R) to arginine (131R) replacement [14]. Fc $\gamma$ RIIa binds with high affinity to IgG1 and IgG3. The amino acid position 131 is polymorphic for IgG2 binding: the $131 \mathrm{H}$ variant can bind to IgG2 with high affinity, while 131R barely binds to IgG2 [13]. For Fc $\gamma$ RIIa, a T > G substitution can occur at amino acid position 158 resulting in valine (158V) to phenylalanine (158F) replacement. The Fc $\gamma$ RIIIa-158V variant was shown to bind to IgG1 and IgG3 with a higher affinity compared to Fc $\gamma$ RIIIa-158F [15].

The FcyRIIa (131H/R) and FcyRIIIa (158F/V) polymorphisms are associated with clinical response for several clinical-approved mAbs including rituximab, trastuzumab, and cetuximab [16-18].

\section{2. $C D C$}

Therapeutic IgG1 antibodies can activate the classical pathway of the complement system by binding of the $\mathrm{Fc}$ region to the complement protein $\mathrm{C} 1 \mathrm{q}$, which initiates a cascade of proteolytic cleavage steps. This results in formation of the membrane attack complex (MAC), consisting of the complement products $\mathrm{C} 5 \mathrm{~b}$ to $\mathrm{C} 9$. The MAC generates pores in the cell membrane which initiates target cell lysis, termed complement-dependent cytotoxicity (CDC) [19]. Similar to Fc $\gamma \mathrm{R}$, the affinity of C1q for IgG-Fc is low and binding is dependent on multivalent IgG-antigen immune complexes to provide sufficient avidity [20-22]. The ability of IgG1 antibodies to activate the complement pathway is highly dependent on antigen density, size, and fluidity [23-25]. High-resolution crystallography studies have recently revealed that, dependent on such factors, specific non-covalent interactions between IgG Fc domains induce ordered hexamer formation (mAb hexamerization) on the cell surface that provides a docking platform for the six-globular-headed C1q molecule and thereby efficiently activates the complement pathway [26].

\section{Fc Engineering to Enhance Fc-Effector Functions}

The hinge and the proximal $\mathrm{C}_{\mathrm{H}} 2$ regions of the $\mathrm{Fc}$ tail are considered critical for $\mathrm{Fc}_{\mathrm{c}}$ interaction with $\mathrm{F}_{\mathrm{C}} \gamma \mathrm{Rs}$ and $\mathrm{C} 1 \mathrm{q}$. The interface of these regions contains the binding sites, while the structural conformation of the $\mathrm{C}_{\mathrm{H}} 2$ domain allows engagement of $\mathrm{C} 1 \mathrm{q}$ or $\mathrm{Fc} \gamma \mathrm{R}$. In addition, the $\mathrm{C}_{\mathrm{H}} 2$ domains are post-translationally modified by asparagine $(N) 297$-linked glycosylation, and glycosylation and the specific glycan composition contribute to the stability and the dynamics of the $\mathrm{C}_{\mathrm{H}} 2$ domains [27-29]. Glycan components include core units of $\mathrm{N}$-acetylglucosamine (GlcNAc) and mannose, with additional variations in galactose, bisecting GlcNAc, fucose, and sialic acid.

Detailed understanding of $\mathrm{Fc}_{\mathrm{c}}$ interactions with $\mathrm{C} 1 \mathrm{q}$ and $\mathrm{Fc} \gamma \mathrm{R}$ opened up opportunities to modulate $\mathrm{C} 1 \mathrm{q}$ and $\mathrm{Fc} \gamma \mathrm{R}$ binding by Fc engineering. In order to enhance ADCC, ADCP, and CDC, studies have employed site-directed mutagenesis (sequence variations), Fc glycosylation modification (glycoengineering), and avidity modulation, which will be outlined below. 


\subsection{Enhancing ADCC}

\subsubsection{Glycoengineering to Enhance Fc $\gamma$ R Affinity}

Fc glycosylation is required for binding the low-affinity Fc $\gamma R$ [30,31]. Generally, aglycosylation is thought to completely abrogate $\mathrm{F}_{\mathrm{C}} \gamma \mathrm{R}$ effector functions [32,33], but several aglycosylated $\mathrm{Fc}_{\mathrm{c}}$ variants with intact $F c \gamma R$ effector function have been reported [34-36]. Altering the specific composition of the Fc glycan can increase the affinity for Fc $\gamma$ R. The removal of core fucose (afucosylation) has been shown to highly increase Fc $\gamma$ RIIIa binding affinity and consequently increase ADCC [37,38] (Figure 2A). This effect has been attributed to an interaction between the Fc-glycan and the N-glycan attached to Asn 162 of the Fc $\gamma$ RIIIa [39], however, the exact nature of the interaction is still debated. It has been suggested that core fucose restricts the number of conformations recognized by the Fc $\gamma$ RIIIa N-glycan [40], while others suggest that core fucose inhibits direct carbohydrate-carbohydrate interactions with the receptor glycan [41,42]. Nevertheless, afucosylation is widely accepted as an effective approach to increase the potency of IgG1 antibodies to induce ADCC.

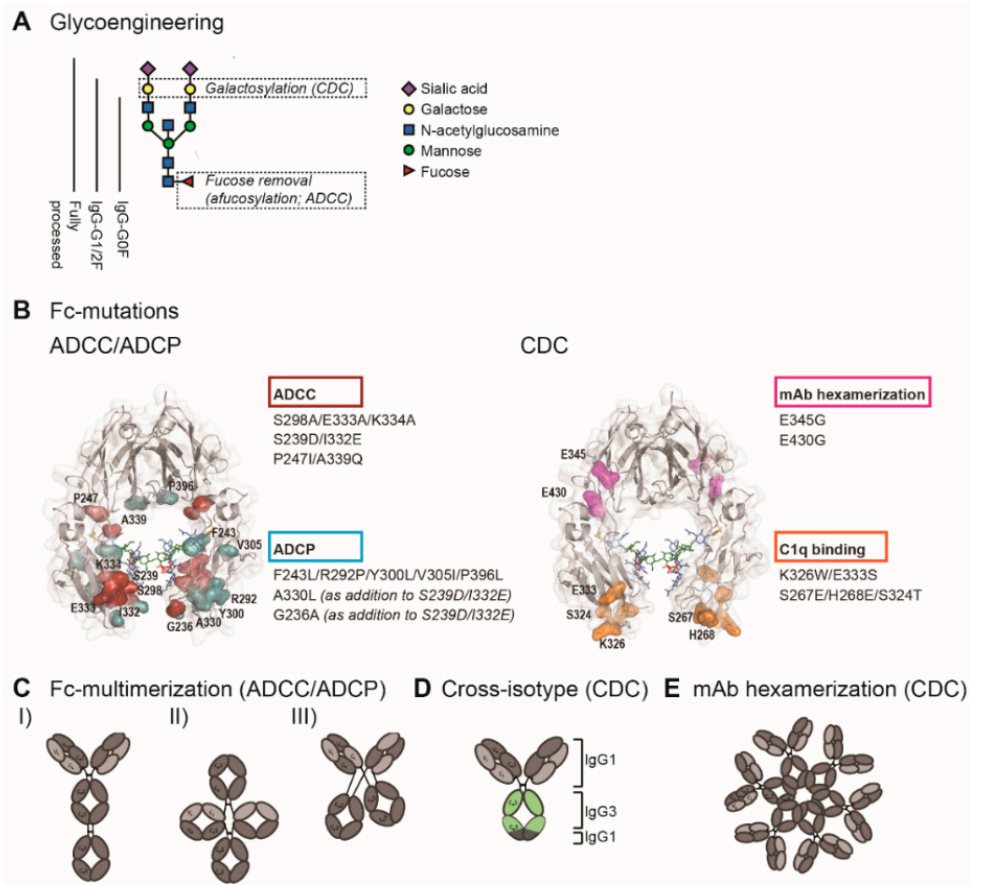

Figure 2. Fc engineering strategies to enhance Fc-effector functions. (A) The biantennary complex glycan structure of the most frequent variants for the N-glycan of therapeutic IgG (G0F, G1F, G2F, and fully processed). Glycoengineering strategies focus on galactosylation for enhanced CDC and afucosylation for enhanced ADCC. (B) ADCC/ADCP (left) and CDC (right) enhancing point mutations depicted in the crystal structure of the Fc region (PDB:3DO3). The ADCC-enhancing mutations S298A/E333A/K334A, S239D/I3332E, and P247I/A339Q are depicted in magenta; the ADCP-enhancing mutations F234L/R292P/Y300L/V305I/P396L, A330L, and G236A are shown in blue. A330L and G236A were added to the ADCC-enhancing mutations S239D/I332E to decrease the mutation-related increase in affinity to the inhibitory receptor Fc $\gamma$ RIIb. The CDC-enhancing mutations E345G and E430G, which induce $\mathrm{Fc} / \mathrm{Fc}$ interactions and subsequent $\mathrm{mAb}$ hexamerization (see $\mathrm{E}$ ), are shown in orange and K326W/E333S and S267E/H268E/S324T, which enhance C1q binding affinity, are shown in pink. (C) Schematic representation of three FC multimerization strategies which are aimed to enhance ADCC and ADCP. (D) Cross-isotype antibody generated by replacing the $\mathrm{C}_{\mathrm{H}} 2$ and part of the $\mathrm{C}_{\mathrm{H}} 3$ domains of an IgG1 antibody with the corresponding regions of an IgG3 antibody, to increase the CDC response. (E) Schematic representation of $\mathrm{mAb}$ hexamerization which facilitates $\mathrm{C} 1 \mathrm{q}$ binding and enhances $\mathrm{CDC}$, and can occur upon antigen binding by IgG1 antibodies naturally or when harboring the E345G or E430g mutations. 
To a lesser extent, Fc galactosylation is also suggested to modulate Fc $\gamma$ RIIIa binding. The reported effects of hypergalactosylation on ADCC, however, range from completely absent to positive without addition of afucosylation [38,43,44] and positive with addition of afucosylation [45,46]. These large variations in study results might be explained by differential interactions of the galactose on the different $\mathrm{N}$-glycan arms with Fc $\gamma \mathrm{R}$ [47]. The effects of Fc sialylation on ADCC have been described to be minimal, and completely absent in addition to afucosylation $[43,46,48]$.

\subsubsection{Site-Directed Mutagenesis to Enhance Fc $\gamma$ R Affinity}

High-resolution structural Fc analysis revealed the specific Fc $\gamma$ R-binding sites, which has laid the foundation for structure-guided identification of affinity-enhancing mutations. Fc $\gamma$ Rs interact with residues Leu234-Ser239 on the lower hinge and residues Asp265-Glu269, and Asn297-Thr299 on the $\mathrm{C}_{\mathrm{H}} 2$ domain $[49,50]$. Since then, it has become clear that numerous positions within or in close proximity to this region can be mutated to improve $\mathrm{Fc} \gamma \mathrm{R}$ binding affinity. Alanine screening in the $\mathrm{C}_{\mathrm{H}} 2$ and $\mathrm{C}_{\mathrm{H}} 3$ domains revealed that several mutations could enhance binding to Fc $\gamma$ RIIIa, with the most potent mutations combined in S298A/E333A/K334A for enhanced ADCC [51]. A study using computational design algorithms and high-throughput screening demonstrated that S239D/I332E mutations could also enhance Fc $\gamma$ RIIIa binding and ADCC [52]. Both S298A/E333A/K334A and S239D/I332E highly enhanced binding for the lower-affinity polymorphic variant (F158) of Fc $\gamma$ RIIIa [51,52]. The P247I/A339Q mutations, which were applied in the anti-CD20 mAb ocaratuzumab, have also been shown to enhance binding to the lower-affinity Fc $\gamma$ RIIIa [53] (Figure 2B).

Structural analyses of the Fc-Fc $\gamma R$ interaction have revealed that the $\mathrm{Fc}_{\mathrm{c}}$ binding to $\mathrm{Fc} \gamma \mathrm{R}$ is asymmetrical: the receptor binds to different residues on each $\mathrm{Fc}_{\mathrm{c}}$ domain. Hence, it seemed likely that applying mutations to $\mathrm{Fc}_{\mathrm{C}}$ regions asymmetrically could maximize the $\mathrm{Fc} \gamma \mathrm{R}$ binding affinity. Indeed, $\mathrm{Fc}_{\mathrm{c}}$ heterodimeric antibodies improved $\mathrm{C}_{\mathrm{H}} 2$ domain stability and the consequent Fc $\gamma$ RIIIa binding as compared to a symmetrically mutated Fc variant [54,55]. In addition, afucosylation of the heterodimeric antibodies further improved the Fc $\gamma$ RIIIa binding [55].

\subsubsection{Fc Multimerization}

In comparison to affinity modulation, avidity modulation is a less established but more straightforward approach. Fc duplication (or tandem-Fc) or multiplication, whereby multiple Fcs are linked within one IgG1 molecule, has been shown to augment $\mathrm{Fc} \gamma \mathrm{R}$ binding avidity and increase ADCC and ADCP [56-59] (Figure 2C). A theoretical safety concern for Fc multiplication strategies is the fact that natural antibody oligomerization may result in unwanted immune activation [60]. However, studies have reported minimal in vitro aggregation and no in vivo adverse events so far [57,59].

\subsection{Enhancing $A D C P$}

\subsubsection{Glycoengineering to Enhance Fc $\gamma$ R Affinity}

Strategies enhancing ADCC via increased affinity for Fc $\gamma$ RIIIa on NK cells can also enhance ADCP via increased antibody binding to monocytes and macrophages, since these cells also express Fc $\gamma$ RIIIa. ADCP induced by neutrophils can be improved as well since neutrophils express Fc $\gamma$ RIIIb, which shares 97\% sequence homology with Fc $\gamma$ RIIIa. It has indeed been demonstrated that afucosylated mAbs can induce higher levels of ADCP [61,62].

\subsubsection{Site-Directed Mutagenesis to Enhance Fc $\gamma R$ Affinity}

Different than ADCC, ADCP induction is highly dependent on the balance of binding to the activating receptors versus the inhibitory receptor Fc $\gamma$ RIIb. The activating Fc $\gamma$ RIIa shares $90 \%$ similarities with the inhibitory Fc $\gamma$ RIIb [63]. Hence, selectively increasing Fc $\gamma$ RIIa binding without influencing or while even decreasing the inhibitory Fc $\gamma$ RIIb binding remains a great challenge in enhancing ADCP and requires more careful engineering. Increasing Fc $\gamma$ RIIa binding while simultaneously decreasing Fc $\gamma$ RIIb 
was achieved by mutations F243L/R292P/Y300L/V305I/P396L [64]. In another study, in which ADCC could be enhanced by S239D/I332E mutations, a third mutation (A330L) was necessary to improve ADCP because the sole S239D/I332E mutation also resulted in increased binding to Fc $\gamma$ RIIb [52]. Another study identified the G236A mutation to selectively enhance Fc $\gamma$ RIIa binding. This study demonstrated that the addition of G236A to S239D/I332E and S239D/A330L/I332E resulted in enhanced $\mathrm{ADCP}$, in addition to the improvement of ADCC $[65,66]$ (Figure 2B).

\subsubsection{Fc Multimerization}

Fc multimerization strategies are not Fc $\gamma$ R-specific. Therefore, such strategies will enhance the binding of mAbs to other low-affinity Fc $\gamma$ Rs, including to the inhibitory Fc $\gamma$ RIIb. Nonetheless, it appeared possible to increase Fc $\gamma$ RIIa binding and ADCP by Fc multimers $[57,67]$. However, since binding to the inhibitory Fc $\gamma$ RIIb was also increased [57], Fc multimerization strategies might require further Fc engineering to optimally enhance the ADCP.

\subsection{Enhancing $C D C$}

\subsubsection{Glycoengineering to Enhance C1q Binding Affinity}

While afucosylation significantly enhances ADCC and ADCP by facilitating the interaction with the Fc $\gamma$ RIIIa glycan, it minimally affects CDC [46]. Sialyation seems to have moderate effects on C1q binding. Some studies reported increased and some others reported decreased C1q binding by sialyation $[46,68,69]$. Instead, galactose is the key glycan for $\mathrm{C} 1 \mathrm{q}$ binding. Numerous studies demonstrated enhanced C1q binding and CDC by Fc galactosylation [46,69-71] (Figure 2A). Molecular interactions between galactose and amino acid residues on the $\mathrm{C}_{\mathrm{H}} 2$ domains possibly increase $\mathrm{C} 1 \mathrm{q}$ binding affinity [72]. It has also been suggested that $\mathrm{Fc}_{\mathrm{c}}$ glycosylation modulates $\mathrm{Fc} / \mathrm{Fc}$ interactions and thereby affects not the affinity but the avidity of $\mathrm{C} 1 \mathrm{q}$ binding [73].

\subsubsection{Site-Directed Mutagenesis to Enhance C1q Binding Affinity}

The first structural analysis studies revealed that the residues D270, K322, P329, and P331 of the $\mathrm{C}_{\mathrm{H}} 2$ domain were critical for the interaction with $\mathrm{C} 1 \mathrm{q}[74,75]$. More recently, it has been shown that there are two main interaction sites: residues 266-272 and 294-300 on one $\mathrm{C}_{\mathrm{H}} 2$ domain and residues 325-331 on the other [76]. Mutations in residues located on or in proximity to these binding sites significantly affected C1q binding: the double mutant K326W/E333S and triple mutant S267E/H268E/S324T enhanced C1q binding and CDC [77,78] (Figure 2B). The hinge region also plays a role in complement activation, because this region affects the flexibility of the Fc tail, thereby determining the ability to fix $\mathrm{C} 1 \mathrm{q}$. Indeed, certain mutations in the upper hinge region could enhance C1q binding and CDC [79].

\subsubsection{Antibody Hexamerization to Facilitate C1q Binding}

In addition to affinity modulation, site mutagenesis can also be performed in order to modulate avidity. Proceeding from the finding that antibody hexamers facilitate $\mathrm{C} 1 \mathrm{q}$ binding, the essential first step in CDC, a novel strategy was developed in order to improve the hexamer forming of antibodies upon target antigen binding. Introducing the specific point mutations E345R and E430G at the Fc and $\mathrm{C}_{\mathrm{H}} 2-\mathrm{C}_{\mathrm{H}} 3$ interface could indeed stimulate the $\mathrm{Fc} / \mathrm{Fc}$ interactions between antibodies and facilitate the natural concept of antibody hexamerization, leading to superior $\mathrm{C} 1 \mathrm{q}$ binding and enhanced CDC $[26,80]$ (Figure 2B,E). Since Fc hexamerization by these specific point mutations only occurs upon antigen binding on the cell surface, antibodies generated by this so called "HexaBody" technology retain the pharmacokinetics of conventional IgG1 antibodies. 


\subsubsection{Cross-Isotype Antibodies}

Although both IgG1 and IgG3 can effectively activate complement, IgG3 antibodies can bind C1q more effectively [81]. Therefore, cross-isotype antibodies have been generated by replacing the $\mathrm{C}_{\mathrm{H}} 2$ and $\mathrm{C}_{\mathrm{H}} 3$ domains of an IgG1 antibody with the corresponding regions of an IgG3 antibody, which increases the CDC response [82] (Figure 2D).

\section{Generation of Fc-Engineered mAbs}

Although the hybridoma technology revolutionized the field of therapeutic antibodies, most mAbs that are currently approved for therapeutic use are generated by mammalian expression systems, which allow higher antibody yields and preserve post-translational modifications, generating a higher-quality $\mathrm{mAb}$ product. Mammalian expression systems often use the variable regions derived from the hybridoma or phage display technologies. The sequence of the desired region is cloned into the appropriate expression vector and subsequently transfected into the expression system. Currently available mammalian expression systems include various Chinese hamster ovary $(\mathrm{CHO})$ cell lines, mouse myeloma (NS0), and mouse hybridoma (Sp2/0) cell lines. In addition, several human expression systems are available, including embryonic kidney (HEK293), amniotic (CAP), a hybrid of HEK293 and lymphoma (HKB-11), and embryonic retina (PER.C6). The human expression systems, however, provide transient expression and are therefore only suitable for preclinical purposes.

The current approaches of antibody sequence engineering at the Fc site apply site-directed mutagenesis either directly once heavy and light chain sequences are available (for structure-based sequence engineering) or to generate large phage or yeast display libraries to screen for the most optimal Fc variant (empirical-based sequence engineering). Glycoengineered antibodies require more complex adaptations in the manufacturing protocol, which will be outlined below.

\section{Glycoengineered $m A$ s}

Mammalian expression systems allow conventional post-translational modifications and can also be modified to alter specific post-translational modifications, such as Fc glycosylation. However, glycosylation is a complex process and cannot be controlled completely as cell culture conditions can alter the glycosylation pattern [83,84]. To create glycoengineered antibodies in order to develop antibodies with improved ADCC activity, several modified mammalian expression systems were developed. Double knockout of the enzyme $\alpha 1,6$-fucosyltransferase 8 (FUT8), which catalyzes the transfer of fucose from GDP-fucose to $\mathrm{N}$-acetylglucosamine (GlcNAc), in $\mathrm{CHO}$ cell lines resulted in the production of afucosylated antibodies [85]. Alternatively, $\mathrm{CHO}$ cells were engineered to express $\beta(1,4)-N$-acetylglucosaminyltransferase III (GnTIII). IgGs produced by mammalian cells have very low or no bisecting GlcNAc, in contrast to IgGs present in human serum, and increasing the number of bisecting GlcNAc improved ADCC levels [86,87]).

\section{Clinical Experience with Fc-Engineered mAbs for B-Cell Malignancies}

Although various strategies can enhance ADCC, ADCP, or CDC effector function, they do not uniformly increase these effector functions when applied to different antigens, since antigen binding also affects the $\mathrm{C} 1 \mathrm{q}$ and $\mathrm{Fc} \gamma \mathrm{R}$ binding via structural allostery $[88,89]$. In addition, there is a partial overlap in the Fc-binding sites for $\mathrm{C} 1 \mathrm{q}$ and Fc $\gamma \mathrm{R}$ [6]. Therefore, modulating the Fc tail to enhance $\mathrm{ADCC} / \mathrm{ADCP}$ can negatively influence $\mathrm{CDC}$, and vice versa. It is thus recommended to evaluate Fc-effector function-enhancing strategies for each target individually.

In B-cell malignancies, a wide variety of disease-associated targets are available, including various lineage-specific surface molecules. The Fc-engineered $\mathrm{mAbs}$ for these target antigens are discussed below for each relevant disease subtype (Table 1). 
Table 1. Fc-engineered monoclonal antibodies (mAbs) with enhanced mAb effector function in (pre-) clinical development for chronic lymphocytic leukemia (CLL),

B-cell non-Hodgkin lymphoma (B-NHL), and multiple myeloma (MM).

\begin{tabular}{|c|c|c|c|c|c|c|c|c|}
\hline $\begin{array}{l}\text { Fc-Engineered } \\
\mathrm{mAb}\end{array}$ & Target & Iso-Type & $\begin{array}{l}\text { Chimeric/ } \\
\text { Human(ized) }\end{array}$ & $\begin{array}{l}\text { Fc Engineering } \\
\text { Strategy }\end{array}$ & $\begin{array}{l}\text { Enhanced } \\
\text { Effector } \\
\text { Function }\end{array}$ & $\begin{array}{l}\text { Additional mAb } \\
\text { Engineering }\end{array}$ & $\begin{array}{l}\text { Clinical Stage; } \\
\text { NCT of } \\
\text { Recruiting } \\
\text { Clinical Trials }\end{array}$ & $\begin{array}{l}\text { Major } \\
\text { Indication(s) }\end{array}$ \\
\hline $\begin{array}{l}\text { Obinutuzumab } \\
\text { (GA101;Gazyva) }\end{array}$ & CD20, type II & $\operatorname{IgG2}$ & Humanized & Afucosylation & $\mathrm{ADCC}$ & $\begin{array}{l}\text { Modified elbow } \\
\text { hinge }\end{array}$ & FDA-approved & FL and CLL \\
\hline $\begin{array}{l}\text { Ublituximab } \\
\text { (LFB-R603, } \\
\text { EMAB-6) }\end{array}$ & CD20, type I & IgG1 & Chimeric & Low fucose & ADCC & & Phase $2 / 3^{1}$ & CLL and B-NHL \\
\hline $\begin{array}{l}\text { Ocaratuzumab } \\
\text { (AME-133v, } \\
\text { LY2469298) }\end{array}$ & CD20, type I & $\operatorname{IgG1}$ & Humanized & $\begin{array}{l}\text { Mutations } \\
\text { P247I/A339Q }\end{array}$ & ADCC & $\begin{array}{l}\text { Antigen binding } \\
\text { affinity optimized }\end{array}$ & Discontinued & \\
\hline $\begin{array}{l}\text { PRO131921 } \\
\text { (RhuMAb; v114) }\end{array}$ & CD20, type I & IgG1 & Humanized & Mutations (na) & $\mathrm{ADCC}$ and $\mathrm{CDC}$ & & Discontinued & \\
\hline Ocrelizumab & CD20 & $\operatorname{IgG1}$ & Humanized & Mutations (na) & ADCC & & $\begin{array}{l}\text { Discontinued in } \\
\text { hematology, } \\
\text { approved for } \\
\text { MS }\end{array}$ & MS \\
\hline \multirow[t]{2}{*}{$\begin{array}{l}\text { CD20 double } \\
\text { engineered }\end{array}$} & CD20 & IgG1 & & $\begin{array}{l}\text { Afucosylation+ } \\
\text { mutations } \\
\text { S267E/H268F/ } \\
\text { S324T/G236A/I332E }\end{array}$ & $\mathrm{ADCC}$ and $\mathrm{CDC}$ & & Preclinical & \\
\hline & CD20 & IgG1/IgG3 & & $\begin{array}{l}\text { Afucosylation }+ \\
\text { mixed IgG1/IgG3 } \\
\text { isotype }\end{array}$ & $\mathrm{ADCC}$ and $\mathrm{CDC}$ & & Preclinical & \\
\hline BI 836826 & CD37 & IgG1 & Chimeric & $\begin{array}{l}\text { Mutations } \\
\text { S239D/I332E }\end{array}$ & $\mathrm{ADCC}$ & & Discontinued & \\
\hline
\end{tabular}


Table 1. Cont

\begin{tabular}{|c|c|c|c|c|c|c|c|c|}
\hline $\begin{array}{l}\text { Fc-Engineered } \\
\mathrm{mAb}\end{array}$ & Target & Iso-Type & $\begin{array}{l}\text { Chimeric/ } \\
\text { Human(ized) }\end{array}$ & $\begin{array}{l}\text { Fc Engineering } \\
\text { Strategy }\end{array}$ & $\begin{array}{l}\text { Enhanced } \\
\text { Effector } \\
\text { Function }\end{array}$ & $\begin{array}{l}\text { Additional mAb } \\
\text { Engineering }\end{array}$ & $\begin{array}{l}\text { Clinical Stage; } \\
\text { NCT of } \\
\text { Recruiting } \\
\text { Clinical Trials }\end{array}$ & $\begin{array}{l}\text { Major } \\
\text { Indication(s) }\end{array}$ \\
\hline $\begin{array}{l}\text { DuoHexaBody } \\
\text {-CD37 } \\
\text { (GEN3009) }\end{array}$ & CD37 & IgG1 & Human & $\begin{array}{l}\text { Mutation E430G } \\
\text { (HexaBody) }\end{array}$ & $\mathrm{CDC}$ & $\begin{array}{l}\text { Dual-epitope } \\
\text { targeting }\end{array}$ & Phase $1^{2}$ & B-NHL \\
\hline $\begin{array}{l}\text { Ianalumab } \\
\text { (VAY736; } \\
\text { B-1239) }\end{array}$ & BAFF-R & IgG1 & Human & Afucosylation & ADCC & & Phase $1^{3}$ & CLL \\
\hline $\begin{array}{l}\text { Inebilizumab } \\
\text { (MEDI-551) }\end{array}$ & CD19 & $\operatorname{IgG1\kappa }$ & Humanized & Afucosylation & ADCC & & Phase $1 / 2$ & $\begin{array}{l}\text { B-cell } \\
\text { malignancies }\end{array}$ \\
\hline MDX-1342 & CD19 & & Human & Afucosylation & $\begin{array}{l}\mathrm{ADCC} \text { and } \\
\mathrm{ADCP}\end{array}$ & & Phase 1 halted & \\
\hline $\begin{array}{l}\text { Tafasitamab } \\
\text { (MOR208, } \\
\text { XmAb5574) }\end{array}$ & CD19 & IgG1 & Humanized & $\begin{array}{l}\text { Mutations } \\
\text { S239D/I332E }\end{array}$ & $\begin{array}{l}\mathrm{ADCC} \text { and } \\
\mathrm{ADCP}\end{array}$ & $\begin{array}{l}\text { Antigen binding } \\
\text { affinity optimized }\end{array}$ & $\begin{array}{l}\text { Priority review } \\
\text { granted by FDA }\end{array}$ & $\begin{array}{l}\text { CLL and } \\
\text { DLBCL }\end{array}$ \\
\hline $\begin{array}{l}\text { HexaBody-CD38 } \\
\text { (GEN3014) }\end{array}$ & CD38 & IgG1 & Human & $\begin{array}{l}\text { Mutation E430G } \\
\text { (HexaBody) }\end{array}$ & $\mathrm{CDC}$ & & Preclinical & B-NHL and MM \\
\hline $\begin{array}{l}\text { anti-CD38 } \\
\text { SIFbody }\end{array}$ & CD38 & & & Fc multimerization & $\mathrm{ADCC}$ and $\mathrm{CDC}$ & & Preclinical & $\mathrm{MM}$ \\
\hline \multirow[t]{2}{*}{ XmAb5592 } & HM1.24 & IgG1 & Humanized & $\begin{array}{l}\text { Mutations } \\
\text { S239D/I332E }\end{array}$ & & & & MM \\
\hline & ICAM-1 & IgG1 & Human & $\begin{array}{l}\text { Mutations } \\
\text { S239D/I332E }\end{array}$ & $\begin{array}{l}\text { ADCC and } \\
\text { ADCP }\end{array}$ & & Preclinical & MM \\
\hline SEA-BCMA & BCMA & IgG1 & Humanized & Afucosylation & $\begin{array}{l}\mathrm{ADCC} \text { and } \\
\mathrm{ADCP}\end{array}$ & & Phase $1^{4}$ & MM \\
\hline
\end{tabular}

${ }^{1}$ ClinicalTrials.gov Identifier: NCT03828448; NCT04149821; NCT03801525; NCT02535286; NCT03379051; NCT04016805; NCT02793583. ${ }^{2}$ ClinicalTrials.gov Identifier: NCT04358458. ${ }^{3}$ ClinicalTrials.gov Identifier: NCT03400176. ${ }^{4}$ ClinicalTrials.gov Identifier: NCT03582033. 


\subsection{B-CLL and B-NHL}

\subsubsection{CD20}

CD20 is expressed on almost all healthy and malignant B-cells, but is not expressed by precursor B-cells and plasma cells, making it the ideal therapeutic target for B-cell malignancies [90]. The CD20-targeting chimeric mAb rituximab was the first $\mathrm{mAb}$ to be approved by the FDA for cancer therapy in 1997 and is currently still part of the first line of immune-chemotherapy regimens for patients with B-NHL and CLL. Although rituximab is capable of both ADCC/ADCP and CDC induction, multiple Fc engineering strategies have been explored to enhance the effector functions of CD20-targeting mAbs, either type I or type II. The CD20 mAbs are classified as type I and II based on their ability to reorganize the CD20 molecules into lipid rafts. Type I CD20 mAbs, such as rituximab, can induce CD20 reorganization and efficiently activate the complement pathway, whereas type II CD20 mAbs are poor complement activators but instead induce direct cell death. Both type I and II mAbs can induce ADCC [91,92].

Glycoengineered CD20-targeting mAbs include obinutuzumab (GA101) and ublituximab (TG-1101). Obinutuzumab is a type II glycoengineered (non-fucosylated) humanized anti-CD20 IgG2 mAb which targets a different but overlapping epitope on CD20 compared to rituximab [93]. In comparison to rituximab, a significant clinical benefit of obinutuzumab was observed for FL and CLL in combination with chemotherapy [94-96], and obinutuzumab has received FDA approval for FL and CLL. Obinutuzumab in combination with CHOP (G-CHOP) did not show a PFS benefit compared to R-CHOP for treatment-naïve DLBCL $[97,98]$. Ublituximab is a type I glycoengineered (low-fucose content) chimeric anti-CD20 IgG1 which targets a unique epitope on CD20 and is currently under clinical investigation. Ublituximab increased the ADCC of CLL cells in vitro and ex vivo compared to rituximab $[99,100]$, and induced ADCC in rituximab-resistant B-NHL in in vitro and in vivo models [101]. Ublituximab has shown promising phase 2 and 3 clinical efficacy either as a single agent or in combination with ibrutinib and umbralisib, the first BTK inhibitor and a next-generation PI3K inhibitor, in high-risk CLL and B-NHL patients [102-104]. In addition, several clinical trials are ongoing, including trials investigating the efficacy in treatment-naïve FL and in progressive CLL (ClinicalTrials.gov Identifier: NCT03828448 and NCT04149821, respectively) and a trial investigating the combination of ublituximab with an anti-PDL1 mAb (TG-1501) (ClinicalTrials.gov Identifier: NCT02535286).

The relevance of Fc $\gamma$ RIIIa polymorphisms for antibodies targeting CD20 has been demonstrated by the higher response rates of rituximab in patients with the $158 \mathrm{~V}$ variant $[16,105,106]$. Fc-mutated CD20-targeting $\mathrm{mAbs}$ that were clinically evaluated and designed to enhance affinity for the low-affinity variant Fc $\gamma$ RIIIa-158F include the humanized mAbs ocaratuzumab (AME-133v; LY2469298), PRO131921 (RhuMAb v114), and ocrelizumab. Ocaratuzumab was generated by screening for Fc modifications that enhance ADCC, which led to the identification of the P247I/A339Q mutations that enhanced binding to both allelic variants of Fc $\gamma$ RIIIa, in addition to Fab modifications that enhance antigen binding [107]. In vitro, ocaratuzumab induced ADCC in CLL cells at higher levels than rituximab, and similar levels to obinutuzumab [53]. A phase $1 / 2$ clinical trial demonstrated the activity and tolerability of ocaratuzumab in previously treated FL patients with low-affinity Fc $\gamma$ RIIIa $[108,109]$. PRO131921 is Fc-modified (unspecified) to enhance C1q binding in addition to enhanced Fc $\gamma$ RIIIa binding, and was demonstrated to enhance ADCC and CDC in vitro compared to rituximab. A phase 1 trial of PRO131921 in relapsed and/or refractory follicular lymphoma patients who previously received rituximab showed tolerability [110]. However, the clinical development of both ocaratuzumab and PRO131921 has been discontinued [111], no information regarding the reason has been disclosed. Ocrelizumab demonstrated activity in a phase 1-2 trial in patients with relapsed/refractory follicular lymphoma [112], but is, at the moment, only registered for the treatment of patients with multiple sclerosis.

Several other Fc-engineered CD20-targeting antibodies have been explored in preclinical studies. The strong CDC induction of IgG3 antibodies targeting CD20 [113,114] favors the development of IgG1/IgG3 
isotype variants, and a CD20-targeting afucosylated IgG1/IgG3 isotype variant, with increased CDC and ADCC levels in vitro [115]. Applying multiple Fc-enhancing strategies simultaneously also proved beneficial for a nonfucosylated rituximab variant containing the S267E/H268F/S324T/G236A/I332E mutations, which enhanced both ADCC and CDC in vitro [116].

\subsubsection{CD37}

Similar to CD20, CD37 is expressed on all mature B-cells, but absent or expressed at very low levels on stem cells, precursor B-cells, and plasma cells $[117,118]$. Several CD37-targeting therapeutics have been clinically evaluated, including several immunoconjugates but also two Fc-engineered antibodies. BI 836,826 (MAb 37.1) is an Fc-mutated (S239D/I332E) chimeric IgG1 with enhanced ADCC in addition to pro-apoptotic activity. BI 836,826 demonstrated potent cytotoxicity in CLL cells ex vivo, especially in combination with the PI3K inhibitor idelalisib in relapsed CLL [119,120]. In phase 1 clinical trials in relapsed/refractory CLL and relapsed/refractory B-NHL, acceptable tolerability and preliminary efficacy was observed [121,122]. However, a phase $1 \mathrm{~b} / 2$ trial of $\mathrm{BI} 836,826$ in combination with gemcitabine and oxaliplatin in DLBCL was halted prematurely due to dose-limiting toxicities (DLTs) (ClinicalTrials.gov Identifier: NCT02624492). BI 836,826 has been discontinued from further clinical development. The Fc-engineered DuoHexaBody-CD37 is a biparatopic (dual-epitope-targeting) CD37-targeting IgG1 antibody with the E430G hexamerization-enhancing mutation that induces potent CDC, in contrast to native CD37-targeting antibodies [123]. DuoHexaBody-CD37 showed ex vivo efficacy in B-CLL and various B-NHL (van der Horst et al. [124]), and a first-in-human clinical trial has recently been initiated (ClinicalTrials.gov Identifier: NCT04358458).

\subsubsection{BAFF-R}

B cell-activating factor (BAFF) is an immunomodulatory cytokine which regulates B-cell survival and activation. BAFF can bind to three receptors although only one of them binds BAFF with high specificity: the BAFF receptor (BAFF-R) [125]. BAFF-R is expressed on almost all normal and malignant B-cells, but not on pre-B-cells, and is therefore considered an appropriate target for B-CLL and B-NHL. Ianalumab (VAY736; B-1239) is a fully human BAFF-R-targeting glycoengineered (afucosylated) IgG1 antibody. Although ianalumab also blocks receptor signaling and proliferation, ADCC induction mediated by the afucosylated Fc domain was demonstrated to be crucial for potent cytotoxicity. Furthermore, ianalumab induced higher levels of ADCC in CLL cells than rituximab and the Fc-engineered obinutuzumab, and combining ianalumab with ibrutinib could further enhance efficacy in vivo [126,127]. A phase 1 clinical trial is currently active to evaluate ianalumab in combination with ibrutinib for CLL patients (ClinicalTrials.gov Identifier: NCT03400176).

\subsubsection{CD19}

CD19 expression is restricted to the B-cell lineage but is in contrast to CD20 also expressed on precursor B-cells. CD19 is highly expressed in B-NHL and several leukemias, including CLL and ALL. In addition, although CD19 is generally considered to be absent on plasma cells, it has been shown that some multiple myeloma (MM) cells express CD19 at extremely low density which might suffice for targeted therapy [128]. Unmodified CD19-targeting antibodies induce limited ADCC/ADCP and CDC, partly because they are rapidly internalized [129]. CD19 is therefore mostly used as a target for T-cell engagers, such as bispecific antibodies or chimeric antigen receptors (CARs), but some Fc-engineered CD19-targeting antibodies are also clinically evaluated. The CD19-targeting afucosylated mAbs inebilizumab (MEDI-551) and MDX-1342 and the Fc-mutated (S239D/I332E) mAb tafasitamab (MOR208; XmAb5575) all enhance ADCC levels in vitro relative to native CD19 mAbs [130-132]. Inebilizumab was tested in phase 1 trials and showed tolerability and preliminary efficacy in CLL, FL, DLBCL, and MM [133]. However, phase 2 trials of inebilizumab in combination with chemotherapy in CLL and DLBCL did not show any significant differences in outcome compared to rituximab in combination with chemotherapy (ClinicalTrials.gov Identifier: NCT01466153; ClinicalTrials.gov 
Identifier: NCT01453205). A phase 1 study of inebilizumab in relapsed or refractory advanced B-cell malignancies has recently been completed (ClinicalTrials.gov Identifier: NCT00983619). MDX-1342 has been tested in a phase 1 study in in CLL patients (ClinicalTrials.gov Identifier: NCT00593944), but the study was halted prematurely and the program has been discontinued without further disclosure. Tafasitamab was demonstrated safe and efficacious in a phase 1 trial in relapsed CLL and a phase 2 trial in relapsed and refractory B-NHL $[134,135]$. Moreover, in vitro studies suggested that lenalidomide can further enhance the ADCC effects of tafasitamab, and the combination with lenalidomide resulted in a high response rate of relapsed and refractory DLBCL patients. [136]. Tafasitamab has been granted accelerated FDA approval in combination with lenalidomide for patients with relapsed DLBCL.

\subsection{Multiple Myeloma (MM)}

\subsubsection{CD38}

CD38 is an attractive target for multiple myeloma due to its high and uniform expression on MM cells, while its expression on myeloid and lymphoid cells and in non-hematopoietic tissue is relatively low. The unmodified CD38-targeting antibody daratumumab received FDA approval in 2019 and induces MM cell cytotoxicity via ADCC, ADCP, and CDC in addition to direct cell death [137]. To further increase the CDC potential of CD38-targeting antibodies, the Fc-engineered antibody HexaBody-CD38 (GEN3014) carrying the E430G hexamerization-enhancing mutation has been developed. HexaBody-CD38 demonstrated superior CDC activity in vitro compared to daratumumab and showed promising anti-tumor activity in vivo [138]. In addition, the Fc multimerization technology has been employed to generate the anti-CD38 selective immunomodulator of the Fc receptor antibody (SIFbody), with enhanced binding to the Fc $\gamma$ receptors and C1q resulting in CDC activity and NK- and macrophage-mediated killing in vitro. The anti-CD38 SIFbody also demonstrated increased efficacy ex vivo compared to daratumumab [139].

\subsubsection{HM1.24}

HM1.24 was first described to be preferentially overexpressed on normal and malignant plasma cells $[140,141]$, although more recent studies also demonstrated HM1.24 expression on B-CLL and lymphoma and several solid tumors [142-146]. Antibodies targeting HM1.24 for MM exhibited in vitro and in vivo anti-tumor activity. However, a phase 1 study of the humanized anti-HM1.24 unmodified antibody AHM in relapsed/refractory MM could not demonstrate significant efficacy. Glycoengineered (afucosylated) variants of AHM and the Fc-mutated (S239D/I332E) anti-HM1.24 antibody XmAb5592 could enhance ADCC as well as ADCP compared to AHM in preclinical studies, and warrant further clinical testing [147-149].

\subsubsection{ICAM-1}

The intercellular adhesion molecule-1 (ICAM-1/CD54) mediates adhesion of MM cells to bone marrow stromal cells (BMSCs). CD54 is highly expressed on MM cells and associated with advanced disease stage and resistance to chemotherapy, which makes ICAM- 1 an interesting target for MM [150,151]. The unmodified ICAM-1-targeting antibody BI-505 induced potent anti-myeloma activity in vitro and in vivo, which was predominantly macrophage-mediated [152]. BI-505 progressed to clinical trials, and although a phase I trial demonstrated good tolerability, BI-505 lacked significant efficacy in a phase II trial in MM [153,154]. To potentially enhance efficacy in vivo, Fc engineering (S239D/I332E) has been applied to the anti-ICAM-1 fully human IgG1 antibody MSH-TP15, which binds to a distinct but overlapping epitope compared to BI-505, with enhanced ADCC and ADCP activity in vitro and improved tumor control in vivo compared to its unmodified counterpart $[155,156]$. 


\subsubsection{BCMA}

B-cell maturation antigen (BCMA; CD269; TNFRSF17) plays a significant role in the differentiation of B-cells to plasma cells and is required for plasma cell longevity [157]. BCMA expression is specific for plasma cells and MM cells even overexpress BCMA [158]. Multiple T-cell engagers targeting BCMA are currently being clinically evaluated and expected to receive approval for clinical application soon. SEA-BCMA is a glycoengineered (afucosylated) humanized BCMA-targeting IgG1 antibody and showed promising preclinical activity via induction of ADCC and ADCP as well as a block in proliferation [159]. SEA-BCMA is currently evaluated in a phase 1 safety study in relapsed/refractory MM patients (ClinicalTrials.gov Identifier: NCT03582033).

\section{Conclusions and Future Perspective}

In this review, we have illustrated various strategies to enhance Fc-mediated effector functions and we have summarized their clinical application in chronic lymphocytic leukemia (CLL), B-cell non-Hodgkin lymphoma (B-NHL), and multiple myeloma (MM). Fc-mediated effector functions are being enhanced to increase their anti-tumor potency or when a specific effector function is beneficial, i.e., improving ADCC induction for combination therapy with lenalidomide or in patients with low-affinity Fc $\gamma R$ polymorphisms. In addition, Fc engineering can be applied to antibodies which depend on antibody clustering or Fc $\gamma \mathrm{R}$-mediated antibody crosslinking for agonism of receptors, such as antibodies targeting the costimulatory protein CD40 or antibodies targeting death receptors 4 or 5 , and thus benefit from similar strategies as discussed here [160-162].

Generally, mAbs that are Fc-engineered to improve their effector functions are capable of enhancing in vitro and in vivo anti-tumor potency compared to their parental unmodified $\mathrm{mAb}$. Various Fc-engineered $\mathrm{mAbs}$ also demonstrated clinical efficacy, and are already approved for clinical use. However, other Fc-engineered mAbs demonstrated toxicity in clinical trials or failed to induce significant clinical efficacy, and were discontinued for development. Increasing the clinical success of Fc-engineered $\mathrm{mAbs}$ requires more empirical in vitro/in vivo screening to determine the most favorable Fc engineering strategy or combination of strategies. In addition, understanding (i) the specific contribution of ADCC, ADCP, and CDC to the clinical efficacy of mAbs in hematological malignancies and (ii) the exact clinical effect of the different $F_{c}$ engineering strategies could allow for developing $F_{c}$ engineering strategies customized to a specific target and disease. A step forward in understanding the specific contribution of $\mathrm{mAb}$ effector functions is the recent development of Fc engineering strategies that enhance CDC specifically, such as the HexaBody technology. Until recently, clinically evaluated mAbs were mostly Fc-engineered to enhance ADCC function. Hence, evaluating Fc-engineered mAbs with enhanced CDC and potentially comparing them to mAbs with enhanced ADCC could provide crucial information regarding the contribution of $\mathrm{mAb}$ effector functions to clinical efficacy and toxicity, and the results of such clinical trials are highly anticipated.

To conclude, our advanced knowledge of Fc structure and Fc-mediated effector function has enabled the clinical development of Fc-engineered mAbs. Expanding our clinical experience with these Fc-engineered mAbs will provide valuable information that could allow the development of antibodies with tailor-made effector functions.

Author Contributions: Writing—original draft preparation, H.J.v.d.H.; writing—review and editing, H.J.v.d.H., I.S.N., T.M. and M.E.D.C. All authors have read and agreed to the published version of the manuscript.

Funding: This research received no external funding.

Acknowledgments: The authors would like to thank Sophie Bliss and Robbert Spaapen for their assistance with the PyMOL Molecular Graphics System in order to generate Figure 2B.

Conflicts of Interest: H.J.H., T.M. and M.E.D.C. are inventors on Genmab patent applications. T.M. has received research support from Janssen Pharmaceuticals, Genmab, Takeda, Onkimmune, and Gadeta. M.E.D.C. has received research support from Gilead, Genmab and Celgene. 


\section{References}

1. Köhler, G.; Milstein, C. Continuous cultures of fused cells secreting antibody of predefined specificity. Nature 1975, 256, 495-497. [CrossRef] [PubMed]

2. Morrison, S.L.; Johnson, M.J.; Herzenberg, L.A.; Oi, V.T. Chimeric human antibody molecules: Mouse antigen-binding domains with human constant region domains. Proc. Natl. Acad. Sci. USA 1984, 81, 6851-6855. [CrossRef] [PubMed]

3. Vaughan, T.J.; Osbourn, J.K.; Tempest, P.R. Human antibodies by design. Nat. Biotechnol. 1998, 16, 535-539. [CrossRef] [PubMed]

4. Kaplon, H.; Muralidharan, M.; Schneider, Z.; Reichert, J.M. Antibodies to watch in 2020. mAbs 2019, $12,1703531$. [CrossRef]

5. Hamers-Casterman, C.; Atarhouch, T.; Muyldermans, S.; Robinson, G.; Hammers, C.; Songa, E.B.; Bendahman, N.; Hammers, R. Naturally occurring antibodies devoid of light chains. Nature 1993, 363, 446-448. [CrossRef]

6. De Taeye, S.W.; Rispens, T.; Vidarsson, G. The Ligands for Human IgG and Their Effector Functions. Antibodies 2019, 8, 30. [CrossRef]

7. Brezski, R.J.; Georgiou, G. Immunoglobulin isotype knowledge and application to Fc engineering. Curr. Opin. Immunol. 2016, 40, 62-69. [CrossRef]

8. Swisher, J.F.A.; Feldman, G.M. The many faces of Fc $\gamma$ RI: Implications for therapeutic antibody function. Immunol. Rev. 2015, 268, 160-174. [CrossRef] [PubMed]

9. Daëron, M. Fc receptor biology. Annu. Rev. Immunol. 1997, 15, 203-234. [CrossRef] [PubMed]

10. Bruhns, P. Properties of mouse and human IgG receptors and their contribution to disease models. Blood 2012, 119, 5640-5649. [CrossRef] [PubMed]

11. Ewang, W.; Erbe, A.K.; Hank, J.A.; Morris, Z.S.; Sondel, P.M. NK cell-mediated antibody-dependent cellular cytotoxicity in cancer immunotherapy. Front. Immunol. 2015, 6, 368. [CrossRef]

12. Bournazos, S.; Wang, T.T.; Dahan, R.; Maamary, J.; Ravetch, J.V. Signaling by Antibodies: Recent Progress. Annu. Rev. Immunol. 2017, 35, 285-311. [CrossRef] [PubMed]

13. Hargreaves, C.E.; Rose-Zerilli, M.J.J.; Machado, L.R.; Iriyama, C.; Hollox, E.J.; Cragg, M.S.; Strefford, J.C. Fc $\gamma$ receptors: Genetic variation, function, and disease. Immunol. Rev. 2015, 268, 6-24. [CrossRef] [PubMed]

14. Warmerdam, P.A.; Van De Winkel, J.G.; Vlug, A.; Westerdaal, N.A.; Capel, P.J. A single amino acid in the second Ig-like domain of the human Fc gamma receptor II is critical for human IgG2 binding. J. Immunol. 1991, 147, 1338-1343. [PubMed]

15. Bruggeman, C.W.; Dekkers, G.; Bentlage, A.E.H.; Treffers, L.W.; Nagelkerke, S.Q.; Lissenberg-Thunnissen, S.; Koeleman, C.A.M.; Wuhrer, M.; Berg, T.K.V.D.; Rispens, T.; et al. Enhanced Effector Functions Due to Antibody Defucosylation Depend on the Effector Cell Fc $\gamma$ Receptor Profile. J. Immunol. 2017, 199, $204-211$. [CrossRef] [PubMed]

16. Weng, W.-K.; Levy, R. Two Immunoglobulin G Fragment C Receptor Polymorphisms Independently Predict Response to Rituximab in Patients with Follicular Lymphoma. J. Clin. Oncol. 2003, 21, 3940-3947. [CrossRef] [PubMed]

17. Musolino, A.; Naldi, N.; Bortesi, B.; Pezzuolo, D.; Capelletti, M.; Missale, G.; Laccabue, D.; Zerbini, A.; Camisa, R.; Bisagni, G.; et al. Immunoglobulin G fragment C receptor polymorphisms and clinical efficacy of trastuzumab-based therapy in patients with HER-2/neu-positive metastatic breast cancer. Journal of clinical oncology. Off. J. Am. Soc. Clin. Oncol. 2008, 26, 1789-1796. [CrossRef] [PubMed]

18. Bibeau, F.; Lopez-Crapez, E.; Di Fiore, F.; Thezenas, S.; Ychou, M.; Blanchard, F.; Lamy, A.; Penault-Llorca, F.; Frébourg, T.; Michel, P.; et al. Impact of Fc\{gamma\}RIIa-Fc\{gamma\}RIIIa polymorphisms and KRAS mutations on the clinical outcome of patients with metastatic colorectal cancer treated with cetuximab plus irinotecan. Off. J. Am. Soc. Clin. Oncol. 2009, 27, 1122-1129. [CrossRef]

19. Reis, E.S.; Mastellos, D.C.; Ricklin, D.; Mantovani, A.; Lambris, J.D. Complement in cancer: Untangling an intricate relationship. Nat. Rev. Immunol. 2017, 18, 5-18. [CrossRef] [PubMed]

20. Burton, D.R.; Boyd, J.; Brampton, A.D.; Easterbrook-Smith, S.B.; Emanuel, E.J.; Novotny, J.; Rademacher, T.W.; Van Schravendijk, M.R.; Sternberg, M.J.E.; Dwek, R.A. The C1q receptor site on immunoglobulin G. Nature 1980, 288, 338-344. [CrossRef]

21. Udaka, K.; Okada, M.; Utsumi, S. Co-operation between the pair of C gamma 2 domains in Clq-binding by rabbit IgG. Mol. Immunol. 1986, 23, 1103-1110. [CrossRef] 
22. Utsumi, S.; Okada, M.; Udaka, K.; Amano, T. Preparation and biologic characterization of fragments containing dimeric and monomeric C gamma 2 domain of rabbit IgG. Mol. Immunol. 1985, 22, 811-819. [CrossRef]

23. Parce, J.W.; Kelley, D.; Heinzelmann, K. Measurement of antibody-dependent binding, proteolysis, and turnover of $\mathrm{C} 1 \mathrm{~s}$ on liposomal antigens localizes the fluidity-dependent step in C1 activation. Biochim. Biophys. Acta BBA Biomembr. 1983, 736, 92-98. [CrossRef]

24. Hughes-Jones, N.C.; Gorick, B.D.; Howard, J.C.; Feinstein, A. Antibody density on rat red cells determines the rate of activation of the complement component Cl. Eur. J. Immunol. 1985, 15, 976-980. [CrossRef] [PubMed]

25. Teeling, J.L.; French, R.R.; Cragg, M.S.; Brakel, J.V.D.; Pluyter, M.; Huang, H.; Chan, C.; Parren, P.W.H.I.; Hack, C.E.; DeChant, M.; et al. Characterization of new human CD20 monoclonal antibodies with potent cytolytic activity against non-Hodgkin lymphomas. Blood 2004, 104, 1793-1800. [CrossRef] [PubMed]

26. Diebolder, C.A.; Beurskens, F.J.; De Jong, R.N.; Koning, R.I.; Strumane, K.; Lindorfer, M.A.; Voorhorst, M.; Ugurlar, D.; Rosati, S.; Heck, A.J.R.; et al. Complement Is Activated by IgG Hexamers Assembled at the Cell Surface. Science 2014, 343, 1260-1263. [CrossRef] [PubMed]

27. Krapp, S.; Mimura, Y.; Jefferis, R.; Huber, R.; Sondermann, P. Structural Analysis of Human IgG-Fc Glycoforms Reveals a Correlation Between Glycosylation and Structural Integrity. J. Mol. Biol. 2003, 325, 979-989. [CrossRef]

28. Bowden, T.A.; Baruah, K.; Coles, C.H.; Harvey, D.J.; Yu, X.; Song, B.-D.; Stuart, D.I.; Aricescu, A.R.; Scanlan, C.N.; Jones, E.Y.; et al. Chemical and Structural Analysis of an Antibody Folding Intermediate Trapped during Glycan Biosynthesis. J. Am. Chem. Soc. 2012, 134, 17554-17563. [CrossRef]

29. Jefferis, R. Isotype and glycoform selection for antibody therapeutics. Arch. Biochem. Biophys. 2012, 526, $159-166$. [CrossRef]

30. Jefferis, R.; Lund, J.; Pound, J.D. IgG-Fc-mediated effector functions: Molecular definition of interaction sites for effector ligands and the role of glycosylation. Immunol. Rev. 1998, 163, 59-76. [CrossRef]

31. Mimura, Y.; Sondermann, P.; Ghirlando, R.; Lund, J.; Young, S.P.; Goodall, M.; Jefferis, R. Role of oligosaccharide residues of IgG1-Fc in Fc gamma RIIb binding. J. Biol. Chem. 2001, 276, 45539-45547. [CrossRef] [PubMed]

32. Subedi, G.P.; Barb, A. The Structural Role of Antibody N-Glycosylation in Receptor Interactions. Structure 2015, 23, 1573-1583. [CrossRef] [PubMed]

33. Walker, M.R.; Lund, J.; Thompson, K.M.; Jefferis, R. Aglycosylation of human IgG1 and IgG3 monoclonal antibodies can eliminate recognition by human cells expressing Fc $\gamma$ RI and/or Fc $\gamma$ RII receptors. Biochem. J. 1989, 259, 347-353. [CrossRef] [PubMed]

34. Jo, M.; Kwon, H.S.; Lee, K.-H.; Lee, J.C.; Jung, S.T. Engineered aglycosylated full-length IgG FC variants exhibiting improved Fc $\gamma$ RIIIa binding and tumor cell clearance. $m A$ As 2017, 10, 278-289. [CrossRef]

35. Yoon, H.W.; Jo, M.; Ko, S.; Kwon, H.S.; Lim, C.S.; Ko, B.J.; Lee, J.C.; Jung, S.T. Optimal combination of beneficial mutations for improved ADCC effector function of aglycosylated antibodies. Mol. Immunol. 2019, 114, 62-71. [CrossRef] [PubMed]

36. Sazinsky, S.L.; Ott, R.G.; Silver, N.W.; Tidor, B.; Ravetch, J.V.; Wittrup, K. Aglycosylated immunoglobulin G1 variants productively engage activating Fc receptors. Proc. Natl. Acad. Sci. USA 2008, 105, 20167-20172. [CrossRef] [PubMed]

37. Shields, R.L.; Lai, J.; Keck, R.; O'Connell, L.Y.; Hong, K.; Meng, Y.G.; Weikert, S.H.; Presta, L.G. Lack of fucose on human IgG1 N-linked oligosaccharide improves binding to human Fcgamma RIII and antibody-dependent cellular toxicity. J. Biol. Chem. 2002, 277, 26733-26740. [CrossRef]

38. Shinkawa, T.; Nakamura, K.; Yamane, N.; Shoji-Hosaka, E.; Kanda, Y.; Sakurada, M.; Uchida, K.; Anazawa, H.; Satoh, M.; Yamasaki, M.; et al. The Absence of Fucose but Not the Presence of Galactose or BisectingN-Acetylglucosamine of Human IgG1 Complex-type Oligosaccharides Shows the Critical Role of Enhancing Antibody-dependent Cellular Cytotoxicity. J. Biol. Chem. 2002, 278, 3466-3473. [CrossRef]

39. Cambay, F.; Forest-Nault, C.; Dumoulin, L.; Seguin, A.; Henry, O.; Durocher, Y.; De Crescenzo, G. Glycosylation of Fc $\gamma$ receptors influences their interaction with various IgG1 glycoforms. Mol. Immunol. 2020, 121, 144-158. [CrossRef] 
40. Falconer, D.J.; Subedi, G.P.; Marcella, A.M.; Barb, A. Antibody Fucosylation Lowers the Fc $\gamma$ RIIIa/CD16a Affinity by Limiting the Conformations Sampled by the N162-Glycan. ACS Chem. Biol. 2018, 13, $2179-2189$. [CrossRef]

41. Ferrara, C.; Stuart, F.; Sondermann, P.; Brünker, P.; Umaña, P. The carbohydrate at FcgammaRIIIa Asn-162. An element required for high affinity binding to non-fucosylated IgG glycoforms. J. Biol. Chem. 2006, 281, 5032-5036. [CrossRef] [PubMed]

42. Sakae, Y.; Satoh, T.; Yagi, H.; Yanaka, S.; Yamaguchi, T.; Isoda, Y.; Iida, S.; Okamoto, Y.; Kato, K. Conformational effects of N-glycan core fucosylation of immunoglobulin $\mathrm{G} \mathrm{F}_{\mathrm{C}}$ region on its interaction with Fc $\gamma$ receptor IIIa. Sci. Rep. 2017, 7, 13780. [CrossRef] [PubMed]

43. Thomann, M.; Schlothauer, T.; Dashivets, T.; Malik, S.; Avenal, C.; Bulau, P.; Rüger, P.; Reusch, D. In Vitro Glycoengineering of IgG1 and Its Effect on Fc Receptor Binding and ADCC Activity. PLoS ONE 2015, 10, e0134949. [CrossRef]

44. Thomann, M.; Reckermann, K.; Reusch, D.; Prasser, J.; Tejada, M.L. Fc-galactosylation modulates antibody-dependent cellular cytotoxicity of therapeutic antibodies. Mol. Immunol. 2016, 73, 69-75. [CrossRef] [PubMed]

45. Houde, D.; Peng, Y.; Berkowitz, S.A.; Engen, J.R. Post-translational Modifications Differentially Affect IgG1 Conformation and Receptor Binding. Mol. Cell. Proteom. 2010, 9, 1716-1728. [CrossRef]

46. Dekkers, G.; Treffers, L.; Plomp, R.; Bentlage, A.E.H.; De Boer, M.; Koeleman, C.A.M.; Lissenberg-Thunnissen, S.N.; Visser, R.; Brouwer, M.; Mok, J.Y.; et al. Decoding the Human Immunoglobulin G-Glycan Repertoire Reveals a Spectrum of Fc-Receptor- and Complement-Mediated-Effector Activities. Front. Immunol. 2017, 8, 877. [CrossRef] [PubMed]

47. Chung, A.W.; Crispin, M.; Pritchard, L.; Robinson, H.; Gorny, M.K.; Yu, X.; Bailey-Kellogg, C.; Ackerman, M.E.; Scanlan, C.; Zolla-Pazner, S.; et al. Identification of antibody glycosylation structures that predict monoclonal antibody Fc-effector function. AIDS 2014, 28, 2523-2530. [CrossRef]

48. Li, T.; DiLillo, D.J.; Bournazos, S.; Giddens, J.P.; Ravetch, J.V.; Wang, L.-X. Modulating IgG effector function by Fc glycan engineering. Proc. Natl. Acad. Sci. USA 2017, 114, 3485-3490. [CrossRef]

49. Sondermann, P.; Huber, R.; Oosthuizen, V.; Jacob, U. The 3.2-A crystal structure of the human IgG1 Fc fragment-Fc gammaRIII complex. Nature 2000, 406, 267-273. [CrossRef]

50. Caaveiro, J.M.M.; Kiyoshi, M.; Tsumoto, K. Structural analysis of Fc/Fc $\gamma$ R complexes: A blueprint for antibody design. Immunol. Rev. 2015, 268, 201-221. [CrossRef]

51. Shields, R.L.; Namenuk, A.K.; Hong, K.; Meng, Y.G.; Rae, J.; Briggs, J.; Xie, D.; Lai, J.; Stadlen, A.; Li, B.; et al. High resolution mapping of the binding site on human IgG1 for Fc gamma RI, Fc gamma RII, Fc gamma RIII, and FCRn and design of IgG1 variants with improved binding to the Fc gamma R. J. Biol. Chem. 2001, 276, 6591-6604. [CrossRef] [PubMed]

52. Lazar, G.A.; Dang, W.; Karki, S.; Vafa, O.; Peng, J.S.; Hyun, L.; Chan, C.; Chung, H.S.; Eivazi, A.; Yoder, S.C.; et al. Engineered antibody Fc variants with enhanced effector function. Proc. Natl. Acad. Sci. USA 2006, 103, 4005-4010. [CrossRef] [PubMed]

53. Cheney, C.M.; Stephens, D.M.; Mo, X.; Rafiq, S.; Butchar, J.; Flynn, J.M.; A Jones, J.; Maddocks, K.; O'Reilly, A.; Ramachandran, A.; et al. Ocaratuzumab, an Fc-engineered antibody demonstrates enhanced antibody-dependent cell-mediated cytotoxicity in chronic lymphocytic leukemia. mAbs 2014, 6, 748-754. [CrossRef] [PubMed]

54. Mimoto, F.; Igawa, T.; Kuramochi, T.; Katada, H.; Kadono, S.; Kamikawa, T.; Shida-Kawazoe, M.; Hattori, K. Novel asymmetrically engineered antibody Fc variant with superior FcgammaR binding affinity and specificity compared with afucosylated Fc variant. $m A$ bs 2013, 5, 229-236. [CrossRef]

55. Liu, Z.; Gunasekaran, K.; Wang, W.; Razinkov, V.; Sekirov, L.; Leng, E.; Sweet, H.; Foltz, I.; Howard, M.; Rousseau, A.-M.; et al. Asymmetrical Fc Engineering Greatly Enhances Antibody-dependent Cellular Cytotoxicity (ADCC) Effector Function and Stability of the Modified Antibodies. J. Biol. Chem. 2014, 289, 3571-3590. [CrossRef] [PubMed]

56. Nagashima, H.; Tezuka, T.; Tsuchida, W.; Maeda, H.; Kohroki, J.; Masuho, Y. Tandemly repeated Fc domain augments binding avidities of antibodies for Fcgamma receptors, resulting in enhanced antibody-dependent cellular cytotoxicity. Mol. Immunol. 2008, 45, 2752-2763. [CrossRef]

57. Wang, Q.; Chen, Y.; Pelletier, M.; Cvitkovic, R.; Bonnell, J.; Chang, C.-Y.; Koksal, A.C.; O'Connor, E.; Gao, X.; Yu, X.-Q.; et al. Enhancement of antibody functions through Fc multiplications. mAbs 2017, 9, $393-403$. [CrossRef] [PubMed] 
58. Goulet, D.R.; Zwolak, A.; Williams, J.A.; Chiu, M.L.; Atkins, W.M. Design and characterization of novel dual Fc antibody with enhanced avidity for Fc receptors. Proteins Struct. Funct. Bioinform. 2020, 88, 689-697. [CrossRef]

59. Sustmann, C.; Dickopf, S.; Regula, J.T.; Kettenberger, H.; Mølhøj, M.; Gassner, C.; Weininger, D.; Fenn, S.; Manigold, T.; Kling, L.; et al. DuoMab: A novel CrossMab-based IgG-derived antibody format for enhanced antibody-dependent cell-mediated cytotoxicity. $m A$ bs 2019, 11, 1402-1414. [CrossRef]

60. Tada, M.; Aoyama, M.; Ishii-Watabe, A. Fc $\gamma$ Receptor Activation by Human Monoclonal Antibody Aggregates. J. Pharm. Sci. 2020, 109, 576-583. [CrossRef]

61. Shibata-Koyama, M.; Iida, S.; Misaka, H.; Mori, K.; Yano, K.; Shitara, K.; Satoh, M. Nonfucosylated rituximab potentiates human neutrophil phagocytosis through its high binding for FcgammaRIIIb and MHC class II expression on the phagocytotic neutrophils. Exp. Hematol. 2009, 37, 309-321. [CrossRef] [PubMed]

62. Herter, S.; Birk, M.C.; Klein, C.; Gerdes, C.; Umana, P.; Bacac, M. Glycoengineering of Therapeutic Antibodies Enhances Monocyte/Macrophage-Mediated Phagocytosis and Cytotoxicity. J. Immunol. 2014, 192, 2252-2260. [CrossRef] [PubMed]

63. Rankin, C.T.; Veri, M.-C.; Gorlatov, S.; Tuaillon, N.; Burke, S.; Huang, L.; Inzunza, H.D.; Li, H.; Thomas, S.; Johnson, S.; et al. CD32B, the human inhibitory $\mathrm{Fc}_{\mathrm{C}} \gamma$ receptor IIB, as a target for monoclonal antibody therapy of B-cell lymphoma. Blood 2006, 108, 2384-2391. [CrossRef] [PubMed]

64. Stavenhagen, J.B.; Gorlatov, S.; Tuaillon, N.; Rankin, C.T.; Li, H.; Burke, S.; Huang, L.; Vihj, S.; Johnson, S.; Bonvini, E. Fc optimization of therapeutic antibodies enhances their ability to kill tumor cells in vitro and controls tumor expansion in vivo via low-affinity activating Fcgamma receptors. Cancer Res. 2007, 67, 8882-8890. [CrossRef] [PubMed]

65. Richards, J.O.; Karki, S.; Lazar, G.A.; Chen, H.; Dang, W.; Desjarlais, J.R. Optimization of antibody binding to FcgammaRIIa enhances macrophage phagocytosis of tumor cells. Mol. Cancer Ther. 2008, 7, 2517-2527. [CrossRef] [PubMed]

66. Ahmed, A.A.; Keremane, S.R.; Vielmetter, J.; Bjorkman, P.J. Structural characterization of GASDALIE Fc bound to the activating Fc receptor Fc $\gamma$ RIIIa. J. Struct. Biol. 2016, 194, 78-89. [CrossRef]

67. Nagashima, H.; Ootsubo, M.; Fukazawa, M.; Motoi, S.; Konakahara, S.; Masuho, Y. Enhanced antibody-dependent cellular phagocytosis by chimeric monoclonal antibodies with tandemly repeated Fc domains. J. Biosci. Bioeng. 2011, 111, 391-396. [CrossRef]

68. Quast, I.; Keller, C.W.; Maurer, M.A.; Giddens, J.; Tackenberg, B.; Wang, L.-X.; Munz, C.; Nimmerjahn, F.; Dalakas, M.C.; Lünemann, J.D. Sialylation of IgG Fc domain impairs complement-dependent cytotoxicity. J. Clin. Investig. 2015, 125, 4160-4170. [CrossRef]

69. Wada, R.; Matsui, M.; Kawasaki, N. Influence of N-glycosylation on effector functions and thermal stability of glycoengineered IgG1 monoclonal antibody with homogeneous glycoforms. mAbs 2018, 11, 350-372. [CrossRef]

70. Peschke, B.; Keller, C.W.; Weber, P.; Quast, I.; Lünemann, J.D. Fc-Galactosylation of Human Immunoglobulin Gamma Isotypes Improves C1q Binding and Enhances Complement-Dependent Cytotoxicity. Front. Immunol. 2017, 8, 646. [CrossRef]

71. Hodoniczky, J.; Zheng, Y.Z.; James, D.C. Control of Recombinant Monoclonal Antibody Effector Functions by Fc N-Glycan Remodeling in Vitro. Biotechnol. Prog. 2005, 21, 1644-1652. [CrossRef] [PubMed]

72. Raju, T.S. Terminal sugars of Fc glycans influence antibody effector functions of IgGs. Curr. Opin. Immunol. 2008, 20, 471-478. [CrossRef] [PubMed]

73. Wang, G.; De Jong, R.N.; Bremer, E.T.V.D.; Beurskens, F.J.; Labrijn, A.F.; Ugurlar, D.; Gros, P.; Schuurman, J.; Parren, P.W.; Heck, A.J.R. Molecular Basis of Assembly and Activation of Complement Component C1 in Complex with Immunoglobulin G1 and Antigen. Mol. Cell 2016, 63, 135-145. [CrossRef] [PubMed]

74. Idusogie, E.E.; Presta, L.G.; Gazzano-Santoro, H.; Totpal, K.; Wong, P.Y.; Ultsch, M.; Meng, Y.G.; Mulkerrin, M.G. Mapping of the C1q Binding Site on Rituxan, a Chimeric Antibody with a Human IgG1 Fc. J. Immunol. 2000, 164, 4178-4184. [CrossRef]

75. Thommesen, J.E.; Michaelsen, T.E.; Løset, G.Å.; Sandlie, I.; Brekke, O.H. Lysine 322 in the human IgG3 $\mathrm{CH} 2$ domain is crucial for antibody dependent complement activation. Mol. Immunol. 2000, 37, 995-1004. [CrossRef] 
76. Ugurlar, D.; Howes, S.C.; De Kreuk, B.-J.; Koning, R.I.; De Jong, R.N.; Beurskens, F.J.; Schuurman, J.; Koster, A.J.; Sharp, T.H.; Parren, P.W.H.I.; et al. Structures of C1-IgG1 provide insights into how danger pattern recognition activates complement. Science 2018, 359, 794-797. [CrossRef]

77. Idusogie, E.E.; Wong, P.Y.; Presta, L.G.; Gazzano-Santoro, H.; Totpal, K.; Ultsch, M.; Mulkerrin, M.G. Engineered Antibodies with Increased Activity to Recruit Complement. J. Immunol. 2001, 166, 2571-2575. [CrossRef] [PubMed]

78. Moore, G.L.; Chen, H.; Karki, S.; Lazar, G.A. Engineered Fc variant antibodies with enhanced ability to recruit complement and mediate effector functions. $m A$ ss 2010, 2, 181-189. [CrossRef]

79. Dall'Acqua, W.F.; Cook, K.E.; Damschroder, M.M.; Woods, R.M.; Wu, H. Modulation of the effector functions of a human IgG1 through engineering of its hinge region. J. Immunol. 2006, 177, 1129-1138. [CrossRef]

80. De Jong, R.N.; Beurskens, F.J.; Verploegen, S.; Strumane, K.; Van Kampen, M.D.; Voorhorst, M.; Horstman, W.; Engelberts, P.J.; Oostindie, S.C.; Wang, H.-G.; et al. A Novel Platform for the Potentiation of Therapeutic Antibodies Based on Antigen-Dependent Formation of IgG Hexamers at the Cell Surface. PLoS Biol. 2016, 14, e1002344. [CrossRef]

81. Brüggemann, M.; Williams, G.T.; Bindon, C.I.; Clark, M.R.; Walker, M.R.; Jefferis, R.; Waldmann, H.; Neuberger, M.S. Comparison of the effector functions of human immunoglobulins using a matched set of chimeric antibodies. J. Exp. Med. 1987, 166, 1351-1361. [CrossRef] [PubMed]

82. Natsume, A.; In, M.; Takamura, H.; Nakagawa, T.; Shimizu, Y.; Kitajima, K.; Wakitani, M.; Ohta, S.; Satoh, M.; Shitara, K.; et al. Engineered antibodies of IgG1/IgG3 mixed isotype with enhanced cytotoxic activities. Cancer Res. 2008, 68, 3863-3872. [CrossRef] [PubMed]

83. Patel, T.P.; Parekh, R.B.; Moellering, B.J.; Prior, C.P. Different culture methods lead to differences in glycosylation of a murine IgG monoclonal antibody. Biochem. J. 1992, 285, 839-845. [CrossRef] [PubMed]

84. Müthing, J.; Kemminer, S.E.; Conradt, H.S.; Šagi, D.; Nimtz, M.; Kärst, U.; Peter-Katalinić, J. Effects of buffering conditions and culture $\mathrm{pH}$ on production rates and glycosylation of clinical phase I anti-melanoma mouse IgG3 monoclonal antibody R24. Biotechnol. Bioeng. 2003, 83, 321-334. [CrossRef]

85. Yamane-Ohnuki, N.; Kinoshita, S.; Inoue-Urakubo, M.; Kusunoki, M.; Iida, S.; Nakano, R.; Wakitani, M.; Niwa, R.; Sakurada, M.; Uchida, K.; et al. Establishment ofFUT8 knockout Chinese hamster ovary cells: An ideal host cell line for producing completely defucosylated antibodies with enhanced antibody-dependent cellular cytotoxicity. Biotechnol. Bioeng. 2004, 87, 614-622. [CrossRef]

86. Davies, J.; Jiang, L.; Pan, L.-Z.; LaBarre, M.J.; Anderson, D.; Reff, M. Expression of GnTIII in a recombinant anti-CD20 CHO production cell line: Expression of antibodies with altered glycoforms leads to an increase in ADCC through higher affinity for FC $\gamma$ RIII. Biotechnol. Bioeng. 2001, 74, 288-294. [CrossRef] [PubMed]

87. Umaña, P.; Jean-Mairet, J.; Moudry, R.; Amstutz, H.; Bailey, J.E. Engineered glycoforms of an antineuroblastoma IgG1 with optimized antibody-dependent cellular cytotoxic activity. Nat. Biotechnol. 1999, 17, 176-180. [CrossRef] [PubMed]

88. Yogo, R.; Yamaguchi, Y.; Watanabe, H.; Yagi, H.; Satoh, T.; Nakanishi, M.; Onitsuka, M.; Omasa, T.; Shimada, M.; Maruno, T.; et al. The Fab portion of immunoglobulin G contributes to its binding to Fc $\gamma$ receptor III. Sci. Rep. 2019, 9, 1-10. [CrossRef]

89. Zhao, J.; Nussinov, R.; Ma, B. Antigen binding allosterically promotes Fc receptor recognition. $m A b s$ 2018, 11, 58-74. [CrossRef]

90. Cragg, M.S.; Walshe, C.A.; Ivanov, A.O.; Glennie, M.J. The Biology of CD20 and Its Potential as a Target for mAb Therapy. Curr. Dir. Autoimmun. 2004, 8, 140-174. [CrossRef]

91. Boross, P.; Leusen, J.H.W. Mechanisms of action of CD20 antibodies. Am. J. Cancer Res. 2012, 2, 676-690. [PubMed]

92. Cragg, M.S.; Morgan, S.M.; Chan, H.T.C.; Morgan, B.P.; Filatov, A.V.; Johnson, P.W.M.; French, R.R.; Glennie, M.J. Complement-mediated lysis by anti-CD20 mAb correlates with segregation into lipid rafts. Blood 2003, 101, 1045-1052. [CrossRef] [PubMed]

93. Mössner, E.; Brünker, P.; Moser, S.; Püntener, U.; Schmidt, C.; Herter, S.; Grau, R.; Gerdes, C.; Nopora, A.; Van Puijenbroek, E.; et al. Increasing the efficacy of CD20 antibody therapy through the engineering of a new type II anti-CD20 antibody with enhanced direct and immune effector cell-mediated B-cell cytotoxicity. Blood 2010, 115, 4393-4402. [CrossRef] [PubMed] 
94. Marcus, R.E.; Davies, F.A.J.; Ando, K.; Klapper, W.; Opat, S.; Owen, C.J.; Phillips, E.H.; Sangha, R.; Schlag, R.; Seymour, J.F.; et al. Obinutuzumab-Based Induction and Maintenance Prolongs Progression-Free Survival (PFS) in Patients with Previously Untreated Follicular Lymphoma: Primary Results of the Randomized Phase 3 GALLIUM Study. Blood 2016, 128, 6. [CrossRef]

95. Goede, V.; Fischer, K.; Busch, R.; Engelke, A.; Eichhorst, B.; Wendtner, C.M.; Chagorova, T.; De La Serna, J.; Dilhuydy, M.-S.; Illmer, T.; et al. Obinutuzumab plus Chlorambucil in Patients with CLL and Coexisting Conditions. N. Engl. J. Med. 2014, 370, 1101-1110. [CrossRef]

96. Marcus, R.; Davies, A.; Ando, K.; Klapper, W.; Opat, S.; Owen, C.; Phillips, E.; Sangha, R.; Schlag, R.; Seymour, J.F.; et al. Obinutuzumab for the First-Line Treatment of Follicular Lymphoma. N. Engl. J. Med. 2017, 377, 1331-1344. [CrossRef] [PubMed]

97. Sehn, L.H.; Martelli, M.; Trněný, M.; Liu, W.; Bolen, C.R.; Knapp, A.; Sahin, D.; Sellam, G.; Vitolo, U. A randomized, open-label, Phase III study of obinutuzumab or rituximab plus CHOP in patients with previously untreated diffuse large B-Cell lymphoma: Final analysis of GOYA. J. Hematol. Oncol. 2020, $13,71$. [CrossRef] [PubMed]

98. Vitolo, U.; Trněný, M.; Belada, D.; Burke, J.M.; Carella, A.M.; Chua, N.; Abrisqueta, P.; Demeter, J.; Flinn, I.; Hong, X.; et al. Obinutuzumab or Rituximab Plus Cyclophosphamide, Doxorubicin, Vincristine, and Prednisone in Previously Untreated Diffuse Large B-Cell Lymphoma. J. Clin. Oncol. 2017, 35, 3529-3537. [CrossRef]

99. De Romeuf, C.; Dutertre, C.A.; Le Garff-Tavernier, M.; Fournier, N.; Gaucher, C.; Glacet, A.; Jorieux, S.; Bihoreau, N.; Behrens, C.K.; Béliard, R.; et al. Chronic lymphocytic leukaemia cells are efficiently killed by an anti-CD20 monoclonal antibody selected for improved engagement of FcgammaRIIIA/CD16. Br. J. Haematol. 2008, 140, 635-643. [CrossRef]

100. Le Garff-Tavernier, M.; Herbi, L.; De Romeuf, C.; Nguyen-Khac, F.; Davi, F.; Grelier, A.; Boudjoghra, M.; Maloum, K.; Choquet, S.; Urbain, R.; et al. Antibody-dependent cellular cytotoxicity of the optimized anti-CD20 monoclonal antibody ublituximab on chronic lymphocytic leukemia cells with the 17p deletion. Leukemia 2014, 28, 230-233. [CrossRef]

101. Barth, M.J.; Pendurti, G.; Tsai, P.-C.; Mavis, C.; Klener, P.; Czuczman, M.S.; Hernandez-Ilizaliturri, F. Ofatumumab (OFA) Is a Novel Anti-CD20 Monoclonal Antibody (mAb) with Improved Anti-Tumor Activity in Vitro and in Vivo in Mantle Cell Lymphoma (MCL) Pre-Clinical Models. Blood 2012, 120, 2757. [CrossRef]

102. Sawas, A.; Farber, C.M.; Schreeder, M.T.; Khalil, M.Y.; Mahadevan, D.; Deng, C.; Amengual, J.E.; Nikolinakos, P.G.; Kolesar, J.M.; Kuhn, J.G.; et al. A phase 1/2 trial of ublituximab, a novel anti-CD20 monoclonal antibody, in patients with B-cell non-Hodgkin lymphoma or chronic lymphocytic leukaemia previously exposed to rituximab. Br. J. Haematol. 2017, 177, 243-253. [CrossRef]

103. Sharman, J.P.; Farber, C.M.; Mahadevan, D.; Schreeder, M.T.; Brooks, H.D.; Kolibaba, K.S.; Fanning, S.; Klein, L.; Greenwald, D.R.; Sportelli, P.; et al. Ublituximab (TG-1101), a novel glycoengineered anti-CD20 antibody, in combination with ibrutinib is safe and highly active in patients with relapsed and/or refractory chronic lymphocytic leukaemia: Results of a phase 2 trial. Br. J. Haematol. 2016, 176, 412-420. [CrossRef] [PubMed]

104. Sharman, J.P.; Brander, D.M.; Mato, A.R.; Ghosh, N.; Schuster, S.J.; Kambhampati, S.; Burke, J.M.; Lansigan, F.; Schreeder, M.T.; Lunin, S.D.; et al. Effect of adding ublituximab to ibrutinib on PFS, ORR, and MRD negativity in previously treated high-risk chronic lymphocytic leukemia: Final results of the GENUINE phase III study. J. Clin. Oncol. 2020, 38, 8022. [CrossRef]

105. Persky, D.O.; Dornan, D.; Goldman, B.H.; Braziel, R.M.; Fisher, R.I.; Leblanc, M.; Maloney, D.G.; Press, O.W.; Miller, T.P.; Rimsza, L.M. Fc gamma receptor 3a genotype predicts overall survival in follicular lymphoma patients treated on SWOG trials with combined monoclonal antibody plus chemotherapy but not chemotherapy alone. Haematologica 2012, 97, 937-942. [CrossRef] [PubMed]

106. Kim, N.H.; Jung, H.D.; Kim, J.G.; Lee, J.-J.; Yang, D.-H.; Park, Y.H.; Do, Y.R.; Shin, H.-J.; Kim, M.K.; Hyun, M.S.; et al. FCGR3A gene polymorphisms may correlate with response to frontline R-CHOP therapy for diffuse large B-cell lymphoma. Blood 2006, 108, 2720-2725. [CrossRef]

107. Bowles, J.A.; Wang, S.-Y.; Link, B.K.; Allan, B.; Beuerlein, G.; Campbell, M.-A.; Marquis, D.; Ondek, B.; Wooldridge, J.E.; Smith, B.J.; et al. Anti-CD20 monoclonal antibody with enhanced affinity for CD16 activates NK cells at lower concentrations and more effectively than rituximab. Blood 2006, 108, 2648-2654. [CrossRef] 
108. Forero-Torres, A.; De Vos, S.; Pohlman, B.L.; Pashkevich, M.; Cronier, D.M.; Dang, N.H.; Carpenter, S.P.; Allan, B.W.; Nelson, J.G.; Slapak, C.A.; et al. Results of a Phase 1Study of AME-133v (LY2469298), an Fc-Engineered Humanized Monoclonal Anti-CD20 Antibody, in Fc $\gamma$ RIIIa-Genotyped Patients with Previously Treated Follicular Lymphoma. Clin. Cancer Res. 2012, 18, 1395-1403. [CrossRef] [PubMed]

109. Ganjoo, K.N.; De Vos, S.; Pohlman, B.L.; Flinn, I.W.; Forero-Torres, A.; Enas, N.H.; Cronier, D.M.; Dang, N.H.; Foon, K.A.; Carpenter, S.P.; et al. Phase 1/2 Study of Ocaratuzumab, an Fc-Engineered Humanized Anti-CD20 Monoclonal Antibody, in Low-Affinity Fc $\gamma$ RIIIa Patients with Previously Treated Follicular Lymphoma. Leuk. Lymphoma 2014, 56, 42-48. [CrossRef] [PubMed]

110. Friedberg, J.W.; Vose, J.M.; Kahl, B.S.; Brunvand, M.W.; Goy, A.; Kasamon, Y.L.; Burington, B.; Li, J.; Ho, W.; Cheson, B.D. A Phase I Study of PRO131921, a Novel Anti-CD20 Monoclonal Antibody in Patients with Relapsed/Refractory CD20+ Indolent NHL: Correlation Between Clinical Responses and AUC Pharmacokinetics. Blood 2009, 114, 3742. [CrossRef]

111. Cartron, G.; Watier, H. Obinutuzumab: What is there to learn from clinical trials? Blood 2017, 130, 581-589. [CrossRef] [PubMed]

112. Morschhauser, F.; Marlton, P.; Vitolo, U.; Lindén, O.; Seymour, J.F.; Crump, M.; Coiffier, B.; Foà, R.; Wassner, E.; Burger, H.-U.; et al. Results of a phase I/II study of ocrelizumab, a fully humanized anti-CD20 mAb, in patients with relapsed/refractory follicular lymphoma. Ann. Oncol. 2010, 21, 1870-1876. [CrossRef] [PubMed]

113. Rösner, T.; Derer, S.; Kellner, C.; DeChant, M.; Lohse, S.; Vidarsson, G.; Peipp, M.; Valerius, T. An IgG3 switch variant of rituximab mediates enhanced complement-dependent cytotoxicity against tumour cells with low CD20 expression levels. Br. J. Haematol. 2013, 161, 282-286. [CrossRef] [PubMed]

114. Schwanbeck, R.; Skof, A.; Rösner, T.; Jansen, M.; Räuchle, A.; Kretschmer, A.; Scheidig, A.; Leusen, J.H.W.; Derer, S.; Valerius, T. Abstract 4601: Mechanisms of action for therapeutic antibody variants of human IgG3 isotype: Enhancing the CDC activity of cetuximab and rituximab. Cancer Res. 2017, 77 (Suppl. S13), 4601. [CrossRef]

115. Natsume, A.; Shimizu-Yokoyama, Y.; Satoh, M.; Shitara, K.; Niwa, R. Engineered anti-CD20 antibodies with enhanced complement-activating capacity mediate potent anti-lymphoma activity. Cancer Sci. 2009, 100, 2411-2418. [CrossRef] [PubMed]

116. Wirt, T.; Rosskopf, S.; Rösner, T.; Eichholz, K.M.; Kahrs, A.; Lutz, S.; Kretschmer, A.; Valerius, T.; Klausz, K.; Otte, A.; et al. An Fc Double-Engineered CD20 Antibody with Enhanced Ability to Trigger Complement-Dependent Cytotoxicity and Antibody-Dependent Cell-Mediated Cytotoxicity. Transfus. Med. Hemotherapy 2017, 44, 292-300. [CrossRef] [PubMed]

117. Schwartz-Albiez, R.; Dörken, B.; Hofmann, W.; Moldenhauer, G. The B cell-associated CD37 antigen (gp40-52). Structure and subcellular expression of an extensively glycosylated glycoprotein. J. Immunol. 1988, 140, 905-914.

118. Deckert, J.; Park, P.U.; Chicklas, S.; Yi, Y.; Li, M.; Lai, K.C.; Mayo, M.F.; Carrigan, C.N.; Erickson, H.K.; Pinkas, J.; et al. A novel anti-CD37 antibody-drug conjugate with multiple anti-tumor mechanisms for the treatment of B-cell malignancies. Blood 2013, 122, 3500-3510. [CrossRef]

119. Heider, K.-H.; Kiefer, K.; Zenz, T.; Volden, M.; Stilgenbauer, S.; Ostermann, E.; Baum, A.; Lamche, H.; Küpcü, Z.; Jacobi, A.; et al. A novel Fc-engineered monoclonal antibody to CD37 with enhanced ADCC and high proapoptotic activity for treatment of B-cell malignancies. Blood 2011, 118, 4159-4168. [CrossRef]

120. Betrian, S.; Ysebaert, L.; Heider, K.H.; Delord, J.P.; Fournié, J.J.; Quillet-Mary, A. Idelalisib improves CD37 antibody BI 836826 cytotoxicity against chemo-resistant/relapse-initiating CLL cells: A rationale for combination treatment. Blood Cancer J. 2016, 6, e496. [CrossRef]

121. Stilgenbauer, S.; Schleinitz, T.A.; Eichhorst, B.; Lang, F.; Offner, F.; Rossi, J.-F.; Schroyens, W.; Neste, E.V.D.; Ysebaert, L.; Von Wangenheim, U.; et al. Phase 1 first-in-human trial of the anti-CD37 antibody BI 836826 in relapsed/refractory chronic lymphocytic leukemia. Leukemia 2019, 33, 2531-2535. [CrossRef] [PubMed]

122. Kroschinsky, F.; Middeke, J.M.; Janz, M.; Lenz, G.; Witzens-Harig, M.; Bouabdallah, R.; La Rosée, P.; Viardot, A.; Salles, G.; Kim, S.J.; et al. Phase I dose escalation study of BI 836826 (CD37 antibody) in patients with relapsed or refractory B-cell non-Hodgkin lymphoma. Investig. New Drugs 2020. [CrossRef] [PubMed]

123. Oostindie, S.C.; Van Der Horst, H.J.; Kil, L.P.; Strumane, K.; Overdijk, M.B.; Brink, E.N.V.D.; Brakel, J.H.N.V.D.; Rademaker, H.J.; Van Kessel, B.; Noort, J.V.D.; et al. DuoHexaBody-CD37®, a novel biparatopic CD37 antibody with enhanced Fc-mediated hexamerization as a potential therapy for B-cell malignancies. Blood Cancer J. 2020, 10, 1-13. [CrossRef] [PubMed] 
124. van der Horst, H.J.; Oostindie, S.C. Potent preclinical efficacy of DuoHexaBody-CD37 in B-cell malignancies. Hemasphere 2020. under revision.

125. Thompson, J.S.; Bixler, S.A.; Qian, F.; Vora, K.; Scott, M.L.; Cachero, T.G.; Hession, C.; Schneider, P.; Sizing, I.D.; Mullen, C.; et al. BAFF-R, a Newly Identified TNF Receptor That Specifically Interacts with BAFF. Science 2001, 293, 2108-2111. [CrossRef]

126. McWilliams, E.M.; Cheney, C.; Jones, J.A.; Flynn, J.M.M.; Maddocks, K.; Andritsos, L.A.; Huet, H.; Gram, H.; Baeck, J.; Muthusamy, N.; et al. B-1239, a Novel Anti-BAFF-R Afucosylated Human Antibody, Promotes Potent Natural Killer Cell- Mediated Antibody Dependent Cellular Cytotoxicity In Chronic Lymphocytic Leukemia Cells In- Vitro and Depletion Of Circulating Leukemic CLL B Cells In-Vivo. Blood 2013, 122, 4185. [CrossRef]

127. McWilliams, E.M.; Lucas, C.R.; Chen, T.; Harrington, B.K.; Wasmuth, R.; Campbell, A.; Rogers, K.A.; Cheney, C.M.; Mo, X.; Andritsos, L.A.; et al. Anti-BAFF-R antibody VAY-736 demonstrates promising preclinical activity in CLL and enhances effectiveness of ibrutinib. Blood Adv. 2019, 3, 447-460. [CrossRef]

128. Nerreter, T.; Letschert, S.; Götz, R.; Doose, S.; Danhof, S.; Einsele, H.; Sauer, M.; Hudecek, M. Super-resolution microscopy reveals ultra-low CD19 expression on myeloma cells that triggers elimination by CD19 CAR-T. Nat. Commun. 2019, 10, 3137. [CrossRef] [PubMed]

129. Scheuermann, R.H.; Racila, E. CD19 Antigen in Leukemia and Lymphoma Diagnosis and Immunotherapy. Leuk. Lymphoma 1995, 18, 385-397. [CrossRef] [PubMed]

130. Herbst, R.; Wang, Y.; Gallagher, S.; Mittereder, N.; Kuta, E.; Damschroder, M.M.; Woods, R.; Rowe, D.C.; Cheng, L.; Cook, K.; et al. B-Cell Depletion In Vitro and In Vivo with an Afucosylated Anti-CD19 Antibody. J. Pharmacol. Exp. Ther. 2010, 335, 213-222. [CrossRef]

131. Cardarelli, P.M.; Rao-Naik, C.; Chen, S.; Huang, H.; Pham, A.; Moldovan-Loomis, M.-C.; Pan, C.; Preston, B.; Passmore, D.; Liu, J.; et al. A nonfucosylated human antibody to CD19 with potent B-cell depletive activity for therapy of B-cell malignancies. Cancer Immunol. Immunother. 2010, 59, 257-265. [CrossRef]

132. Horton, H.M.; Bernett, M.J.; Pong, E.; Peipp, M.; Karki, S.; Chu, S.Y.; Richards, J.O.; Vostiar, I.; Joyce, P.F.; Repp, R.; et al. Potent In vitro and In vivo Activity of an Fc-Engineered Anti-CD19 Monoclonal Antibody against Lymphoma and Leukemia. Cancer Res. 2008, 68, 8049-8057. [CrossRef] [PubMed]

133. Ohmachi, K.; Ogura, M.; Suehiro, Y.; Ando, K.; Uchida, T.; Choi, I.; Ogawa, Y.; Kobayashi, M.; Fukino, K.; Yokoi, Y.; et al. A multicenter phase I study of inebilizumab, a humanized anti-CD19 monoclonal antibody, in Japanese patients with relapsed or refractory B-cell lymphoma and multiple myeloma. Int. J. Hematol. 2019, 109, 657-664. [CrossRef] [PubMed]

134. Woyach, J.A.; Awan, F.; Flinn, I.W.; Berdeja, J.G.; Wiley, E.; Mansoor, S.; Huang, Y.; Lozanski, G.; Foster, P.A.; Byrd, J.C. A phase 1 trial of the Fc-engineered CD19 antibody XmAb5574 (MOR00208) demonstrates safety and preliminary efficacy in relapsed CLL. Blood 2014, 124, 3553-3560. [CrossRef] [PubMed]

135. Jurczak, W.; Zinzani, P.; Gaidano, G.; Goy, A.; Provencio, M.; Nagy, Z.; Robak, T.; Maddocks, K.; Buske, C.; Ambarkhane, S.; et al. Phase IIa study of the CD19 antibody MOR208 in patients with relapsed or refractory B-cell non-Hodgkin's lymphoma. Ann. Oncol. 2018, 29, 1266-1272. [CrossRef] [PubMed]

136. Salles, G.; Duell, J.; Barca, E.G.; Tournilhac, O.; Jurczak, W.; Liberati, A.M.; Nagy, Z.; Obr, A.; Gaidano, G.; André, M.; et al. Tafasitamab plus lenalidomide in relapsed or refractory diffuse large B-cell lymphoma (L-MIND): A multicentre, prospective, single-arm, phase 2 study. Lancet Oncol. 2020, 21, 978-988. [CrossRef]

137. Van De Donk, N.W.; Usmani, S.Z. CD38 Antibodies in Multiple Myeloma: Mechanisms of Action and Modes of Resistance. Front. Immunol. 2018, 9, 2134. [CrossRef] [PubMed]

138. De Goeij, B.E.; Janmaat, M.L.; Andringa, G.; Kil, L.; Van Kessel, B.; Frerichs, K.A.; Lingnau, A.; Freidig, A.; Mutis, T.; Sasser, A.K.; et al. Hexabody-CD38, a Novel CD38 Antibody with a Hexamerization Enhancing Mutation, Demonstrates Enhanced Complement-Dependent Cytotoxicity and Shows Potent Anti-Tumor Activity in Preclinical Models of Hematological Malignancies. Blood 2019, 134 (Suppl. S1), 3106. [CrossRef]

139. Choudhury, A.; Ortiz, D.F.; Argueta, S.; Garofalo, K.; Lansing, J.C.; Jetley, U.; Wilkins, D.; Bosques, C.; Cochran, E.; Bhatnagar, N.; et al. Abstract 561: Discovery of a potential best-in-class anti-CD38 therapeutic utilizing Fc multimerization. Cancer Res. 2019, 79 (Suppl. S13). [CrossRef]

140. Goto, T.; Kennel, S.J.; Abe, M.; Takishita, M.; Kosaka, M.; Solomon, A.; Saito, S. A novel membrane antigen selectively expressed on terminally differentiated human B cells. Blood 1994, 84, 1922-1930. [CrossRef] 
141. Ohtomo, T.; Sugamata, Y.; Ozaki, Y.; Ono, K.; Yoshimura, Y.; Kawai, S.; Koishihara, Y.; Ozaki, S.; Kosaka, M.; Hirano, T.; et al. Molecular Cloning and Characterization of a Surface Antigen Preferentially Overexpressed on Multiple Myeloma Cells. Biochem. Biophys. Res. Commun. 1999, 258, 583-591. [CrossRef]

142. Schliemann, C.; Roesli, C.; Kamada, H.; Borgia, B.; Fugmann, T.; Klapper, W.; Neri, D. In vivo biotinylation of the vasculature in B-cell lymphoma identifies BST-2 as a target for antibody-based therapy. Blood 2010, 115, 736-744. [CrossRef] [PubMed]

143. Gong, S.; Osei, E.S.; Kaplan, D.; Chen, Y.H.; Meyerson, H.J. CD317 is over-expressed in B-cell chronic lymphocytic leukemia, but not B-cell acute lymphoblastic leukemia. Int. J. Clin. Exp. Pathol. 2015, 8, 1613-1621. [PubMed]

144. Gramatzki, R.; Szabo, E.; Gramatzki, M.; Peipp, M.; Weller, M. Immu-54. Cd317 expression in human glioblastoma: A target for immunotherapy. Neuro Oncol. 2017, 19 (Suppl. S6), vi124-vi125. [CrossRef]

145. Wang, W.; Nishioka, Y.; Ozaki, S.; Jalili, A.; Abe, S.; Kakiuchi, S.; Kishuku, M.; Minakuchi, K.; Matsumoto, T.; Sone, S. HM1.24 (CD317) is a novel target against lung cancer for immunotherapy using anti-HM1.24 antibody. Cancer Immunol. Immunother. 2009, 58, 967-976. [CrossRef] [PubMed]

146. Yang, L.-L.; Wu, L.; Yu, G.-T.; Zhang, W.-F.; Liu, B.; Sun, Z.-J. CD317 Signature in Head and Neck Cancer Indicates Poor Prognosis. J. Dent. Res. 2018, 97, 787-794. [CrossRef] [PubMed]

147. Ishiguro, T.; Kawai, S.; Habu, K.; Sugimoto, M.; Shiraiwa, H.; Iijima, S.; Ozaki, S.; Matsumoto, T.; Yamada-Okabe, H. A defucosylated anti-CD317 antibody exhibited enhanced antibody-dependent cellular cytotoxicity against primary myeloma cells in the presence of effectors from patients. Cancer Sci. 2010, 101, 2227-2233. [CrossRef]

148. Harada, T.; Ozaki, S.; Oda, A.; Tsuji, D.; Ikegame, A.; Iwasa, M.; Udaka, K.; Fujii, S.; Nakamura, S.; Miki, H.; et al. Combination with a Defucosylated Anti-HM1.24 Monoclonal Antibody plus Lenalidomide Induces Marked ADCC against Myeloma Cells and Their Progenitors. PLoS ONE 2013, 8, e83905. [CrossRef]

149. Tai, Y.-T.; Horton, H.M.; Kong, S.-Y.; Pong, E.; Chen, H.; Cemerski, S.; Bernett, M.J.; Nguyen, D.-H.T.; Karki, S.; Chu, S.Y.; et al. Potent in vitro and in vivo activity of an Fc-engineered humanized anti-HM1.24 antibody against multiple myeloma via augmented effector function. Blood 2012, 119, 2074-2082. [CrossRef]

150. Schmidmaier, R.; Mörsdorf, K.; Baumann, P.; Emmerich, B.; Meinhardt, G. Evidence for Cell Adhesion-Mediated Drug Resistance of Multiple Myeloma Cells in Vivo. Int. J. Biol. Markers 2006, 21, 218-222. [CrossRef]

151. Sampaio, M.S.S.; Vettore, A.L.; Yamamoto, M.; Chauffaille, M.L.; Zago, M.A.; Colleoni, G.W.B. Expression of eight genes of nuclear factor-kappa B pathway in multiple myeloma using bone marrow aspirates obtained at diagnosis. Histol. Histopathol. 2009, 24, 991-997.

152. Veitonmäki, N.; Hansson, M.; Zhan, F.; Sundberg, A.; Löfstedt, T.; Ljungars, A.; Li, Z.-C.; Martinsson-Niskanen, T.; Zeng, M.; Yang, Y.; et al. A Human ICAM-1 Antibody Isolated by a Function-First Approach Has Potent Macrophage-Dependent Antimyeloma Activity In Vivo. Cancer Cell 2013, 23, 502-515. [CrossRef] [PubMed]

153. Hansson, M.; Gimsing, P.; Badros, A.; Nahi, H.; Offner, F.; Salomo, M.; Sonesson, E.; Mau-Sørensen, M.; Stenberg, Y.; Sundberg, A.; et al. A Phase I Dose-Escalation Study of Antibody BI-505 in Relapsed/Refractory Multiple Myeloma. Clin. Cancer Res. 2015, 21, 2730-2736. [CrossRef] [PubMed]

154. Wichert, S.; Juliusson, G.; Johansson, Å.; Sonesson, E.; Teige, I.; Wickenberg, A.T.; Frendeus, B.; Korsgren, M.; Hansson, M. A single-arm, open-label, phase 2 clinical trial evaluating disease response following treatment with BI-505, a human anti-intercellular adhesion molecule-1 monoclonal antibody, in patients with smoldering multiple myeloma. PLoS ONE 2017, 12, e0171205. [CrossRef] [PubMed]

155. Klausz, K.; Cieker, M.; Kellner, C.; Oberg, H.H.; Kabelitz, D.; Valerius, T.; Burger, R.; Gramatzki, M.; Peipp, M. A novel Fc-engineered human ICAM-1/CD54 antibody with potent anti-myeloma activity developed by cellular panning of phage display libraries. Oncotarget 2017, 8, 77552-77566. [CrossRef]

156. Klausz, K.; Cieker, M.; Kellner, C.; Rösner, T.; Otte, A.; Krohn, S.; Lux, A.; Nimmerjahn, F.; Valerius, T.; Gramatzki, M.; et al. Fc-engineering significantly improves the recruitment of immune effector cells by anti-ICAM-1 antibody MSH-TP15 for myeloma therapy. Haematology 2020. [CrossRef]

157. O'Connor, B.P.; Raman, V.S.; Erickson, L.D.; Cook, W.J.; Weaver, L.K.; Ahonen, C.; Lin, L.-L.; Mantchev, G.T.; Bram, R.J.; Noelle, R.J. BCMA Is Essential for the Survival of Long-lived Bone Marrow Plasma Cells. J. Exp. Med. 2004, 199, 91-98. [CrossRef]

158. Carpenter, R.O.; Evbuomwan, M.O.; Pittaluga, S.; Rose, J.J.; Raffeld, M.; Yang, S.; Gress, R.E.; Hakim, F.T.; Kochenderfer, J.N. B-cell Maturation Antigen Is a Promising Target for Adoptive T-cell Therapy of Multiple Myeloma. Clin. Cancer Res. 2013, 19, 2048-2060. [CrossRef] 
159. Van Epps, H.; Anderson, M.; Yu, C.; Klussman, K.; Westendorf, L.; Carosino, C.; Manlove, L.; Cochran, J.; Neale, J.; Benjamin, D.; et al. Abstract 3833: SEA-BCMA: A highly active enhanced antibody for multiple myeloma. Immunology 2018, 78, 3833. [CrossRef]

160. Li, F.; Ravetch, J.V. Apoptotic and antitumor activity of death receptor antibodies require inhibitory $\mathrm{F}_{\mathrm{C}} \gamma$ receptor engagement. Proc. Natl. Acad. Sci. USA 2012, 109, 10966-10971. [CrossRef] [PubMed]

161. White, A.L.; Dou, L.; Chan, H.T.C.; Field, V.L.; Mockridge, C.I.; Moss, K.; Williams, E.L.; Booth, S.G.; French, R.R.; Potter, E.A.; et al. Fc $\gamma$ Receptor Dependency of Agonistic CD40 Antibody in Lymphoma Therapy Can Be Overcome through Antibody Multimerization. J. Immunol. 2014, 193, 1828-1835. [CrossRef] [PubMed]

162. Overdijk, M.B.; Strumane, K.; Beurskens, F.J.; Buijsse, A.O.; Vermot-Desroches, C.; Vuillermoz, B.S.; Kroes, T.; De Jong, B.; Hoevenaars, N.; Hibbert, R.G.; et al. Dual epitope targeting and enhanced hexamerization by DR5 antibodies as a novel approach to induce potent anti-tumor activity through DR5 agonism. Mol. Cancer Ther. 2020. [CrossRef] [PubMed]

Publisher's Note: MDPI stays neutral with regard to jurisdictional claims in published maps and institutional affiliations.

(C) 2020 by the authors. Licensee MDPI, Basel, Switzerland. This article is an open access article distributed under the terms and conditions of the Creative Commons Attribution (CC BY) license (http://creativecommons.org/licenses/by/4.0/). 